\title{
Ecological distribution of pelagic copepods and species relationship to acidification, liming and natural recovery in a boreal area
}

\author{
Jens Petter NILSSEN* and Svein Birger WÆRVÅGEN ${ }^{1)}$ \\ AbelCentre for Mathematics and Natural Sciences, Division of Natural Sciences, N - 4980, Gjerstad, Norway \\ ${ }^{1)}$ Hedmark University College, Dept of Agriculture and Natural Sciences, Blæstad, N - 2322 Ridabu, Norway \\ *e-mail corresponding author: jpn@abel.org
}

\begin{abstract}
Distribution and ecology of pelagic copepods were studied in a boreal area strongly affected by acidification in southern Norway. Differential regional composition of bedrock geology and Quaternary deposits combined with liming have produced aquatic sites with contrasting acidification and recovery histories. The omnivorous species Eudiaptomus gracilis showed a striking ability to tolerate both acidification and chemical recovery. The predominantly carnivorous species Heterocope saliens increased numerically during acidification, both because it is tolerant to acidic environments and because fish predation diminished or disappeared altogether. After chemical recovery, H. saliens, having an endogenous egg-bank, most readily produced viable populations with numerical abundance depending upon fish predation pressure. Thermocyclops oithonoides and Cyclops scutifer were negatively affected by strongly acidic environments, whereas Mesocyclops leuckarti tolerated acidic conditions better. All three cyclopoid species increased in abundance after chemical recovery, most probably from small residual populations. The hypolimnetic C. scutifer faced dispersal problems in re-establishing following liming. Deep lakes $(>20 \mathrm{~m})$ harboured considerable residual populations of C. scutifer which recovered rapidly to pre-acidic conditions. Cyclops abyssorum inhabited the pelagial during early recovery of formerly chronically acidified lakes as a fugitive species, probably due to rapid dispersal capacities. Littoral cyclopoids, such as Acanthocyclops vernalis and Diacyclops nanus, were commonly distributed in the free waters of the most acidic lakes $(\mathrm{pH}=4.5-4.8)$, but disappeared from the pelagial shortly after chemical recovery. The total community of pelagic copepods forms a promising tool to identify historical acidification and trajectories of recovery in the freshwater environment.
\end{abstract}

Key words: acidification, autecology, copepod, community resistance, egg-bank, liming, recovery

\section{INTRODUCTION}

Ecological communities are frequently exposed to environmental perturbations, which can be of short- and long-term nature. Acidification of soil and freshwater is normally of long-term nature and have lasted already several decades from the 1950 s until present in geologically susceptible parts of North Europe and North America. Predicting community response to perturbations has become crucial in applied environmental fields, such as conservation biology, ecosystem management, and ecological restoration. Understanding community response is difficult, partly because population densities fluctuate considerably even under socalled stable environmental conditions, and partly because most systems possess many cryptic communityresistant factors through intense competition and predation.

Pelagic calanoid and cyclopoid copepods are being affected to various degrees by the acidification and recovery processes through liming, which includes numerous abiotic and biotic changes in the lake ecosystems (Nilssen et al. 1984b; Sandøy \& Nilssen 1987b; Stenson et al. 1993; Keller \& Yan 1998). Description of copepods' recovery processes remains somewhat incomplete, partly due to limited knowledge of their tax- onomy, autecology, and life histories. The most notable are physiological effects brought about by $\mathrm{pH}$ fluctuations and associated water chemistry (Sandøy \& Nilssen 1987b; Brett 1989). Furthermore, biotic processes connected with fish and invertebrate predators, the latter characterising acidic and fishless ecosystems, are of decisive importance (Eriksson et al. 1980; Nilssen et al. 1984b; Nyman et al. 1985). The most significant life history traits in copepods include: life cycle patterns, microhabitat distribution of all ontogenetical stages, wintering strategies and resting habitats, pattern and type of diapause, egg depositing strategies, and presence of egg-bank. Other important environmental factors form susceptibility to fish and invertebrate predators, dispersal and competitiveness, and physiological tolerance against changes in water chemistry. Information of such life history elements is necessary to obtain in order to fully understand the contrasting tolerance of copepods to acidification and recovery processes, associated with liming and natural recovery of acidified biotopes.

The present area encompasses some of the most seriously affected regions of acidification in southern Norway, and thus in the whole world (Battarbee et al. 1990). It has been investigated since the late 1930s. Substantial acidification processes took place during the 1960-late 1980s, following the major effluents of pollutants from Continental and West Europe within the 
same period (Battarbee et al. 1990). During the last decades the sulphur emissions have decreased about $40 \%$, whereas the nitrogen emissions have only slightly decreased (Henriksen et al. 1997). Some biotopes situated on rich Quaternary deposits in the present area have partly recovered internal buffering systems with a slight pH increase. Simultaneously, many lakes in the strongly acidified, innermost region have been artificially limed using $\mathrm{CaCO}_{3}$ for more than two decades. A considerable area is nevertheless still subject to acidic emissions and has a $\mathrm{pH}$ level close to 4.5 , and virtually no biological improvements during the last four decades.

The pelagic communities studied in the present area include many copepods with partly contrasting life histories and different dormancy traits. The present wholelake manipulations produced by acidification and liming therefore offered unique opportunities to study how pelagic copepods are affected by such ecosystem stress and recovery. These manipulations include first a longterm antropogenic acidification lasting several decades. The chemical neutralisation through liming could probably more precisely be described as a "habitat shock", since it involves considerable chemical alternations within a comparably short period of time.

During recovery, existing species and colonists from internal and external sources interact to form new communities. Evidence of copepod recovery from acidic lakes is scarce, and the available observations do not yet combine to form a coherent picture. The aim of the present study was to describe the structure of the pelagic copepod fauna in lakes of different evolution of acidification and recovery. Furthermore, we wanted to reveal the potential use of pelagic copepods as a biotic tool of such ecosystem stress and recovery, and assess possible community-resistant factors. We also studied how characteristic life history traits, such as life cycle and habitat distribution during plankton and sediment phase, influenced dispersal capacities, community responses, and structure of the new ecosystems.

\section{MATERIAL AND METHODS}

\subsection{Study area and acidification history}

The study area is situated in the boreal region of southern Norway at about $58^{\circ} 50^{\prime} \mathrm{N}$ and $9^{\circ} \mathrm{E}$ (position shown in Fig. 2D). Data on the acidification history (Fig. 1) derive partly from own published (Nilssen 1980; 1982) or unpublished data (Nilssen unpubl. data; Taraldsen unpubl. data), and partly from the Limnobase for the county of Aust-Agder, S Norway. In Norway, each county possesses their own database (so-called Limnobase) with all available historical measurements of water related to liming, freely available from the county fishery officials. In figure 1 , the oldest measurements (before 1961) were done colorimetrically, and after 1961 electrometrically against buffers covering the $\mathrm{pH}$ range.

\subsection{Accumulated chemical and biological data from this region}

Zooplankton have been studied quantitatively and qualitatively in this region since 1973, involving resting stages in the littoral- and profundal-benthic regions (Skov 1985; Wærvågen 1985; Sandøy \& Nilssen 1987a; Sandøy \& Nilssen 1987b; Næss \& Nilssen 1991; Næss et al. 1993; Nilssen \& Wærvågen 2000; Nilssen unpubl. data; Wærvågen unpubl. data). Between 1979 and 1985, 12 lakes were sampled quantitatively every fortnight during the ice-free period and monthly during winter for up to four years (see references above).

Since these life history and dormancy data are not readily available from the literature, they are summarised here, together with a selection of physico-chemical parameters, life history and life cycle relationships for the most common species (Tab. 1). Some species did not possess sediment diapause, and produced only subitaneous eggs, such as the omnivorous, epilimnetic Eudiaptomus gracilis. The euryoecous E. gracilis tolerated considerable fish and invertebrate predation pressure (cf. Nyman et al. 1985; Nassal et al. 1998), although without a spatial refuge it might suffer predation from larvae of Chaoborus spp. The epilimnetic, omnivorous cyclopoids Mesocyclops leuckarti and Thermocyclops oithonoides always exhibited late instar diapause lasting 5-8 months in the sediment during winter. The omnivorous, hypolimnetic Cyclops scutifer was usually perennial in the pelagic zone, whereas in some lakes it showed sediment diapause during winter. Thus, M. leuckarti, T. oithonoides and C. scutifer had winter diapause, the two former in the sediment, and the latter usually in the plankton. The dormancy trait of the important predator in acidic lakes, Heterocope saliens, was conspicuously different. In addition to the annual embryonic egg diapause period of 6-8 months for a fraction of the population, it probably also exhibited a type of "delayed-hatching" dormant eggs (Sandøy \& Nilssen 1987a), probably viable for decades (cf. Chen \& Marcus 1997; Hairston \& Bohonak 1998). The fish predation vulnerable $H$. saliens was restricted to the innermost region, or to lakes acidified for a considerable period of time, situated on barren rocks throughout the region.

The life histories and life cycles of the species $E$. gracilis, H. saliens, C. scutifer, M. leuckarti, $T$. oithonoides, C. strenuus, and rock-pool populations of C. abyssorum are well known due to a number of detailed studies (Tab. 1; ref. above). The life histories of A. vernalis, D. nanus, and hypolimnetic lake populations of $C$. abyssorum are yet insufficiently known in this region. Most species were distributed in the epilimnetic waters, aside from $C$. scutifer and lake populations of $C$. abyssorum, which were mainly found associated with low temperatures (Tab. 1). 
Tab. 1. Pelagic copepods in the present study region related to abiotic and biotic parameters (accumulated data; see Material and methods, 2.2). Selected habitat and physico-chemical factors with upper and lower extreme values shown; - : no data; +++: strongly vulnerable, ++ : vulnerable, +: less vulnerable, 0 : not consumed. Legend: Altitude (m a.s.l.), Depth $\left(\mathrm{Z}_{\mathrm{m}}, \mathrm{m}\right), \mathrm{pH}$, Calcium $\left(\mathrm{Ca} \mathrm{mg} \mathrm{l}^{-1}\right)$, Humus $\left(\mathrm{Pt} \mathrm{mg}^{-1}\right)$, Aluminium (reactive aluminium: $\mu \mathrm{g} \mathrm{l}^{-1}$ ), Total-P (total phosphorous: $\mu \mathrm{g} \mathrm{l}^{-1}$ ), Life cycle (number of generations per year; ${ }^{1}$ : lake populations mainly annual and pond populations diannual; ${ }^{2}$ : some rock-pools populations probably diannual), Diapause (primary pattern of diapause; ${ }^{3}$ : two forms of resting eggs probably produced: annually hatching and delayed-hatching; ${ }^{4}$ : unclear if the species exhibits a late instar plankton diapause like many marine calanoids; ${ }^{5}$ : both pond and lake populations seem to be wintering in the free waters, unclear if this is planktonic diapause; ${ }^{6}$ : the species winters usually in sediment diapause, but with a fraction in plankton diapause), Fish pred. (vulnerability to fish predation in the study area; ${ }^{7}$ : uncommon combination, but the species is probably vulnerable to fish predation when co-occurring).

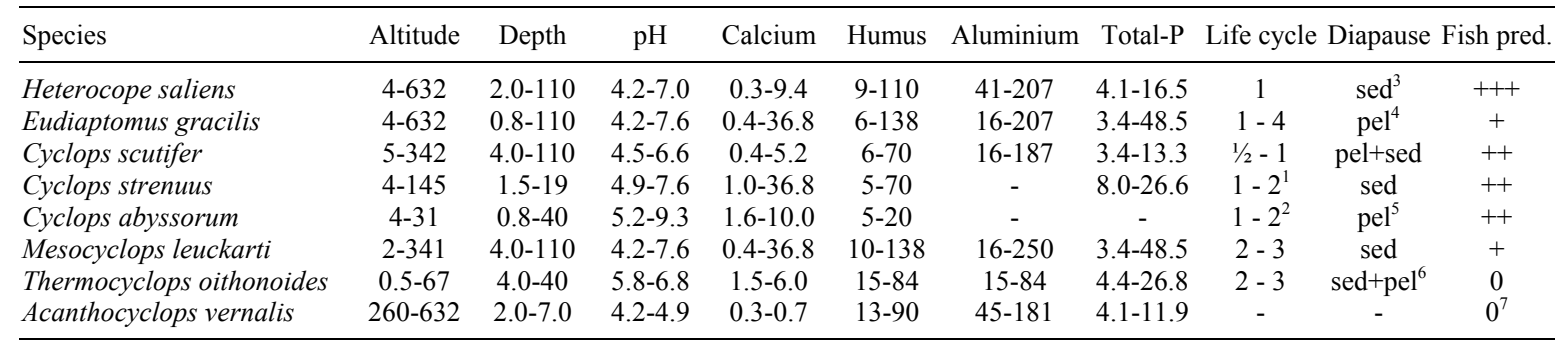

\subsection{Categorisation of lakes: spatial and temporal patterns}

During the process of acidification, lakes develop through different phases with respect to e.g. fish population, zooplankton structure, $\mathrm{pH}$ and alkalinity, which makes it possible to identify several characteristic categories (termed A - D; see below). Similarly, development of a chronically acidic or a less strongly acidic lake to a less acidic or alkaline lake, due to liming and natural processes, passes through different phases. Moreover, we argue that the temporal patterns in lake development can also be identified spatially in this area, since the chemical gradient of lakes from the coast to inland areas, encompasses all lake categories described below.

During the normal succession of acidification, lakes usually start with healthy fish populations, including planktivorous species with all their ontogenetic stages. Then, due to reproductive failure and local species extinction, acid-stressed lakes progress towards a stage where the dominant predators are mainly adult benthivorous non-reproductive fish, to a fish-barren period with invertebrates as dominant planktivorous. A healthy fish population exerts a completely different influence on the zooplankton than the combined effect from nonreproductive adult fish and invertebrate planktivorous. The historical $\mathrm{pH}$ developments in selected lakes characteristic for the whole present area and encompassing the different lake types below, are shown in figure 1 . The different classes of lakes generally fall into five different types (A - D, and E: limed lakes), with different biotic and abiotic characteristics.

- Category A: chronically acidic lakes [Solhomfjell lakes (sites 1-4) and Lake Heilandvann before liming (site 26); Figs 1, 2; Tab. 2] where the buffering capacity is gone and $\mathrm{pH}$ has stabilised at a stable, low level (usually $\mathrm{pH}$ : 4.4-4.8). All fishes are elimi- nated and the new top predators are different species of invertebrates, especially pelagic corixids, larvae of chaoborids, and water beetles. This encompasses primarily the geographically innermost region (inside of site $\mathrm{Gj}$ in Fig. 2B), but also some few isolated lakes situated on acid bedrocks and shallow Quaternary deposits in more base-rich geological areas.

- Category B: lakes where the buffering capacity is almost gone [Lake Gjerstadvann (site Gj, 7); Fig. 1; Tab. 2], and the $\mathrm{pH}$ level is strongly fluctuating and low (usually $\mathrm{pH}$ : 4.8-5.5). Many organisms are affected, including reproduction of most fish species. A typical lake within this category contains mostly old fishes while young planktivorous or brook-living stages are missing.

- Category C: lakes where the buffering capacity is reduced and the $\mathrm{pH}$ is temporarily lowered, usually to $\mathrm{pH}$ : 5.3-5.8 [Lake Mjåvann (site 12); Fig. 1; Tab. 2]. There are no noticeable changes in the biology of the lake and young planktivorous fish are abundant.

- Category D: lake with intact buffering capacity and stable $\mathrm{pH}$, usually above 6.5 [Lake Hovdansvann (site 14); Fig. 1; Tab. 2]. Some sites in this category have in addition a history of natural or antropogenic eutrophication.

- Category E: limed lakes [Lake Heilandsvann after liming (site 26); Fig. 1, Tab. 2], usually originating from categories $\mathrm{A}$ and $\mathrm{B}$, and sometimes $\mathrm{C}$ before liming.

\subsection{Field sampling and laboratory procedure for 1999- 2001}

The present investigation from the summers of 1999-2001 is a preliminary report of the re-establishment of pelagic copepod communities, about two decades after the initiation of the large-scale liming activities of acidification-exposed regions in southern Norway. 
- Solomfjell lakes (A)

$\Delta \cdots$ Lake Heilandsvann (E)

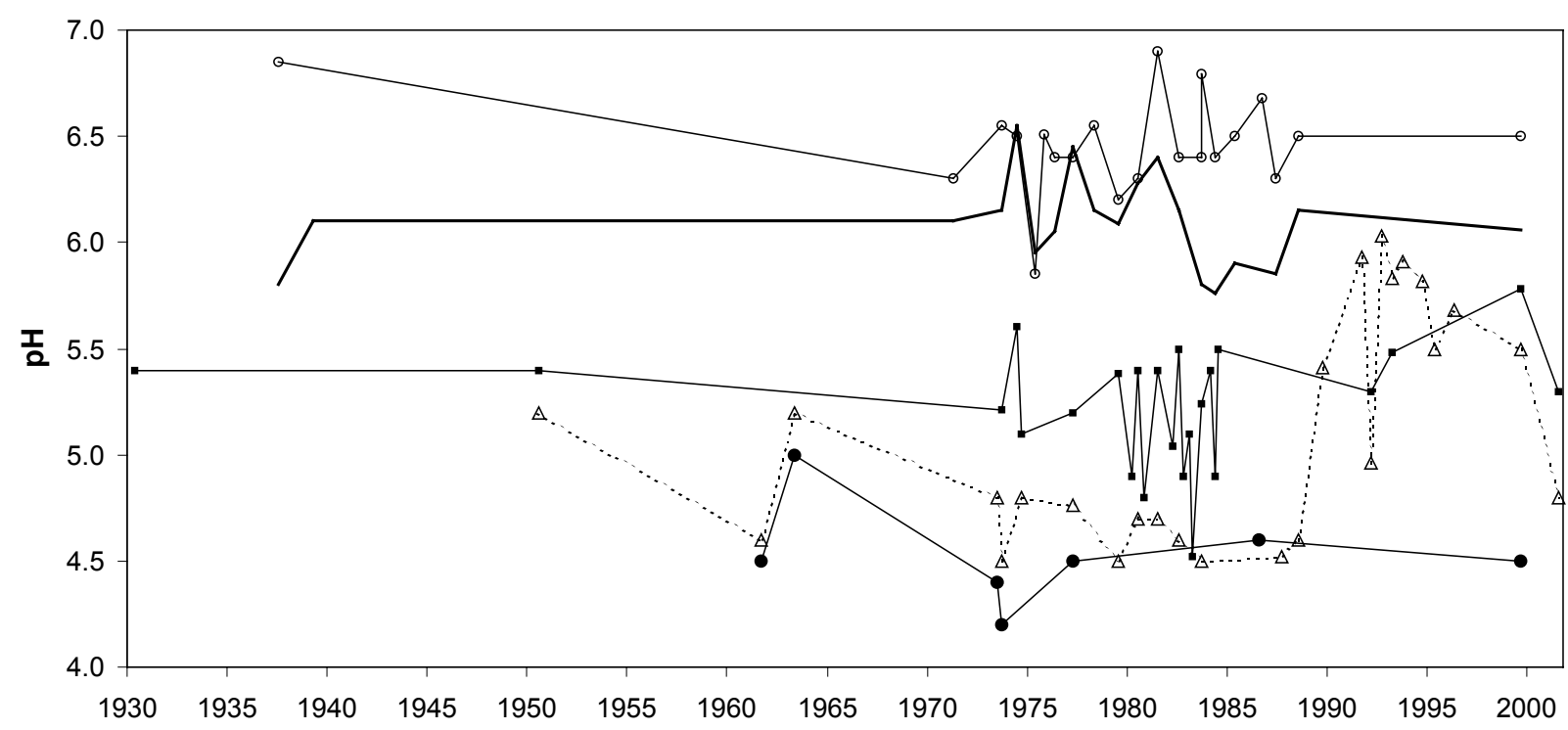

Fig. 1. History of acidification $(\mathrm{pH})$ of selected sites in the investigated region from 1930-2001. The geographical position of the different sites is presented in Fig. 2B. The sites represent category A lakes [Solhomfjell lakes (sites: 1-4); Lake Heilandsvann (site 26; prior to liming in the 1980s)], category B (Lake Gjerstadvann: site 7), category C (Lake Mjåvann: site 12), category D (Lake Hovdansvann: site 14), and category E (Lake Heilandsvann: site 26). Very low pH in Lake Heilandsvann (site 26) and Lake Gjerstadvann (site 7) from late summer to late autumn in 2000 is due to extreme acidic out-fall that year. The sites were more intensively sampled after 1970. See table 2 and text for more details.

Based on the above quantitative studies on zooplankton communities and accumulated data on the region's biogeography described in table 1, we argue that one qualitative net sampling in the period July-September from bottom to surface usually catches adequately all pelagic copepod species in a single lake, except for the summer diapausing C. strenuus. Distribution of the latter species was assessed by sampling sites during March-May 1999-2001, usually below the previously marine limit (cf. Fig. 2A), where the species is restricted. Zooplankton data was based on duplicate plankton net samples (Ø: $25 \mathrm{~cm}$, mesh size $90 \mu \mathrm{m})$ drawn from the bottom to the surface over the deepest part of the lake. Altogether 148 lakes were sampled (Fig. 2); limed and unlimed lakes in different chemical and biological recovery phases. Based on this results, 31 sites covering and representing all lake types $\mathrm{A}-\mathrm{E}$, with a wide range of acidification stress and pre-history were selected (Tab. 2; Fig. 3).

The relationship between $\mathrm{pH}$ and the different pelagic copepods in figure 4 was based upon data in figure 3 and table $2(\mathrm{n}=31)$; species percentage abundance was related to the total abundance of pelagic copepods.

The general sequence of changes in the species composition of major pelagic copepods following recovery from acidification in lakes with contrasting fish predation patterns and stratification types in figure 5, was based on investigated lakes in $1999-2001$ and historical data (Nilssen 1980; 1984; Nilssen \& Wærvågen $2002 b)(n=248)$. We argue that the present distributional pattern of copepods related to $\mathrm{pH}$ also describe the temporal development of the copepod communities in relation to changing $\mathrm{pH}$. The temporal period on the abscissa in figure 5 is approximately 5-15 years, depending upon the residual populations of species after the acidification period, and intensity of fish planktivory in the period following liming. Shallow lakes (stratification type II sensu Hutchinson 1957) with high fish predation from Eurasian perch (Perca fluviatilis) were separated from shallow lakes with low fish predation from brown trout (Salmo trutta) as sole fish, and these classes were separated from deep lakes (stratification type I sensu Hutchinson 1957). Fish predation patters are based on body size measurements of the community key species $D$. longispina (Nilssen \& Wærvågen 2002a; 2002b).

The taxonomy of many pelagic copepods is laborious, especially identification of early ontogenetic stages (Einsle 1975; 1989; Nilssen 1979). The study region is situated outside the centre of cyclopoid distribution in East and Middle Europe, where frequently up to 3-5 species of Cyclops occur simultaneously in the pelagial, 
Tab. 2. The selected lakes, lake categories (see text), acidic stress, and characteristic abiotic parameters. Acidic stress (combined severity and duration): $\mathrm{xxx}$ (very strong), xx (strong), $\mathrm{x}$ (moderately strong), 0: no or negligible acid stress; -: not limed; $\sim$ : approximately (period limed).

\begin{tabular}{|c|c|c|c|c|c|c|c|c|c|c|c|c|c|}
\hline & 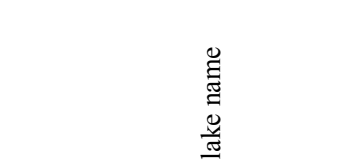 & 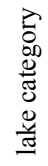 & 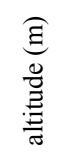 & 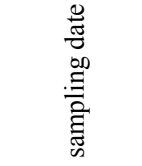 & 壳 & 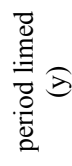 & 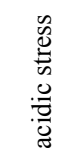 & 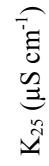 & 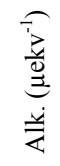 & $\underset{\widetilde{I}}{\stackrel{\overbrace = 0}{\Xi}}$ & 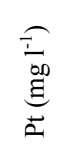 & 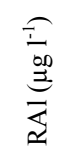 & 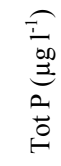 \\
\hline SITE 1 & LILLE KARITJENN & A & 405 & 01/09/1999 & 4.7 & - & XXX & 15 & 12 & 0.4 & 53 & 176 & 7.3 \\
\hline SITE 2 & STORE KARITJENN & A & 426 & $01 / 09 / 1999$ & 4.7 & - & XXX & 15 & 10 & 0.4 & 47 & 181 & 7.6 \\
\hline SITE 3 & NEDRE MARISHEITJENN & A & 542 & 01/09/1999 & 4.7 & - & XXX & 14 & 12 & 0.4 & 36 & 98 & 9.4 \\
\hline SITE 4 & SVINTJENN & A & 562 & 01/09/1999 & 4.7 & - & XXX & 16 & 8 & 0.3 & 13 & 117 & 5.5 \\
\hline SITE 5 & KLEIVVANN & A & 301 & $10 / 08 / 2001$ & 4.7 & - & $\mathrm{XXX}$ & 13 & 5 & 0.4 & 31 & 174 & 8.5 \\
\hline SITE 6 & LUNDVANN & $\mathrm{B}$ & 102 & $10 / 08 / 2001$ & 5.0 & - & XXX & 13 & 18 & 0.9 & 55 & 187 & 10.7 \\
\hline SITE 7 & GJERSTADVANN & B & 31 & $14 / 08 / 2001$ & 5.3 & - & $\mathrm{XX}$ & 15 & 30 & 1.2 & 50 & 150 & 13.0 \\
\hline SITE 8 & SUTVANN & $\mathrm{B}$ & 265 & $10 / 08 / 2001$ & 4.7 & - & XX & 17 & 5 & 0.4 & 8 & 164 & 5.2 \\
\hline SITE 9 & SUTTJENN & $\mathrm{B}$ & 250 & $10 / 08 / 2001$ & 4.7 & - & XX & 15 & 6 & 0.5 & 11 & 146 & 7.1 \\
\hline SITE 10 & ØSTRE KALVVANN & $\mathrm{B}$ & 166 & $14 / 08 / 2001$ & 5.2 & - & $\mathrm{XX}$ & 20 & 30 & 1.1 & 45 & 107 & 8.5 \\
\hline SITE 11 & NERTJENN & $\mathrm{D}$ & 3 & 29/08/1999 & 6.6 & - & 0 & 59 & 210 & 5.0 & 84 & 139 & 26.8 \\
\hline SITE 12 & MJÅVANN & $\mathrm{C}$ & 49 & $13 / 09 / 1999$ & 6.1 & - & $\mathrm{X}$ & 36 & 110 & 1.9 & 49 & 72 & 7.3 \\
\hline SITE 13 & TJOVELITJENN & $\mathrm{C}$ & 140 & $14 / 08 / 2001$ & 5.8 & - & $\mathrm{X}$ & 25 & 50 & 1.5 & 14 & 101 & 8.5 \\
\hline SITE 14 & HOVDANSVANN & $\mathrm{D}$ & 22 & $13 / 09 / 1999$ & 6.5 & - & 0 & 56 & 150 & 3.0 & 15 & 16 & 6.6 \\
\hline SITE 15 & LOMTJENN & $\mathrm{C}$ & 92 & $14 / 08 / 2001$ & 5.4 & - & $\mathrm{X}$ & 27 & 28 & 1.3 & 14 & 64 & 7.4 \\
\hline SITE 16 & LJOSVANN & $\mathrm{E}$ & 351 & $10 / 08 / 2001$ & 5.4 & $\sim 15$ & XXX & 16 & 26 & 1.2 & 11 & 75 & 7.8 \\
\hline SITE 17 & KVERNSMYRTJENN & $\mathrm{E}$ & 82 & $16 / 08 / 2000$ & 5.4 & $\sim 10$ & XXX & 37 & 45 & 1.1 & 19 & 112 & 4.9 \\
\hline SITE 18 & STEMTJENN & $\mathrm{E}$ & 275 & $11 / 09 / 1999$ & 5.6 & $\sim 15$ & XXX & 18 & 40 & 1.3 & 89 & 184 & 16.2 \\
\hline SITE 19 & STÅLTJENN & $\mathrm{E}$ & 111 & $14 / 08 / 2001$ & 5.6 & $\sim 10$ & XXX & 28 & 45 & 1.9 & 46 & 144 & 8.9 \\
\hline SITE 20 & RUNDTJENN & $\mathrm{E}$ & 190 & $14 / 08 / 2001$ & 5.5 & $\sim 10$ & XXX & 27 & 85 & 2.8 & 104 & 174 & 10.7 \\
\hline SITE 21 & KALBERGSVANN & $\mathrm{E}$ & 180 & $31 / 08 / 2000$ & 6.0 & $\sim 15$ & $\mathrm{XX}$ & 24 & 90 & 2.1 & 97 & 178 & 12.3 \\
\hline SITE 22 & SVART & $\mathrm{E}$ & 90 & $14 / 08 / 2001$ & 5.9 & $\sim 15$ & $\mathrm{X}$ & 32 & 65 & 2.5 & 17 & 63 & 8.2 \\
\hline SITE 23 & STORE FINNETJENN & $\mathrm{E}$ & 230 & $11 / 08 / 2001$ & 6.1 & $\sim 20$ & $\mathrm{XX}$ & 21 & 106 & 2.7 & 21 & 100 & 5.6 \\
\hline SITE 24 & ØSTERÅVANN & $\mathrm{E}$ & 46 & $31 / 08 / 2000$ & 6.7 & $\sim 10$ & $\mathrm{XX}$ & 45 & 107 & 2.7 & 14 & 38 & 4.2 \\
\hline SITE 25 & ÅSVANN & $\mathrm{E}$ & 142 & $10 / 08 / 2001$ & 5.9 & $\sim 10$ & $\mathrm{X}$ & 18 & 38 & 0.9 & 37 & 91 & 10.0 \\
\hline SITE 26 & HEILANDSVANN & $\mathrm{E}$ & 225 & $11 / 08 / 2001$ & 4.8 & $\sim 15$ & XXX & 12 & 10 & 0.8 & 59 & 189 & 10.4 \\
\hline SITE 27 & VILITJENN & $\mathrm{E}$ & 184 & $14 / 08 / 2001$ & 5.6 & $\sim 10$ & $\mathrm{XX}$ & 21 & 62 & 2.0 & 72 & 151 & 9.3 \\
\hline SITE 28 & KJELLINGTJENN & $\mathrm{E}$ & 225 & $11 / 08 / 2001$ & 5.0 & $\sim 20$ & XXX & 13 & 20 & 1.2 & 70 & 205 & 9.3 \\
\hline SITE 29 & VEGÅR & $\mathrm{E}$ & 189 & $10 / 08 / 2001$ & 5.7 & $\sim 15$ & $\mathrm{XX}$ & 22 & 48 & 1.7 & 14 & 89 & 6.0 \\
\hline SITE 30 & EVJEVANN & $\mathrm{E}$ & 213 & $01 / 09 / 2000$ & 6.3 & $\sim 15$ & $\mathrm{XX}$ & 21 & 93 & 2.0 & 18 & 80 & 4.2 \\
\hline SITE 31 & MARKSETTJENN & $\mathrm{E}$ & 307 & $11 / 08 / 2001$ & 5.8 & $\sim 20$ & XXX & 18 & 83 & 2.3 & 72 & 149 & 11.9 \\
\hline
\end{tabular}

and makes identification and ecological studies very time consuming (Einsle 1989). In the surveyed area usually $1-3$ species of pelagic cyclopoids coexisted.

Cyclopoid nauplii were not identified to species, but presented as one group; all other copepod instars were identified to species and counted. Between 100-1200 (an average of 210 representative specimens of pelagic copepods) were counted for each lake, to include all species in adequate numbers. For a clearer presentation of copepod species in figure 3, and to counterbalance the high abundance of nauplii and copepodids I-III, we did the following approximation: numbers of all nauplii and copepodid I-III instars were divided by 10 and 5, respectively. We chose this approximation because of different ontogenetic death rates (cf. Landry 1978).

\subsection{Chemical analysis}

Chemical analyses in table 1 and table 2 were performed according to standard analytical methods. $\mathrm{pH}$ was measured electrometrically (Metrohm 691) with a glass electrode, and further titration with diluted $\mathrm{HCl}$ to $\mathrm{pH}=4.5$ to obtain alkalinity. $\mathrm{K} 25$ was analysed with a
Metrohm 644 Conductometer. $\mathrm{Ca}^{2+}$ was analysed on a flame AAS (Perkin-Elmer 460). Pt, RAl and Tot P were measured on a spectrophotometer (Shimadzu UV-1201) at 410,585 and $880 \mathrm{~nm}$ respectively.

\section{RESULTS}

Diagnostic data for the selected lakes investigated in 1999- 2001 (categories A - E) are presented in table 2. Historical $\mathrm{pH}$ development of typical sites from the different geological regions is shown in figure 1 (position see Fig. 2B). These sites characterise the study area from the innermost acidic region to the coast, including all lake categories A (area inside of site $\mathrm{Gj}$ in Fig. 2B) to E. The former postglacial marine limit is situated about $100 \mathrm{~m}$ above present sea levels in the innermost eastern part of the area, decreasing to about $60 \mathrm{~m}$ a.s.l. close to the coast in the south-western part (see Fig. 2AC).

The temporal development of chronically acidic lakes (category A) is represented by the group of Solhomfjell lakes (sites 1-4) and Lake Heilandvann (site 26) before liming (Fig. 1; Tab. 2). The major period of 


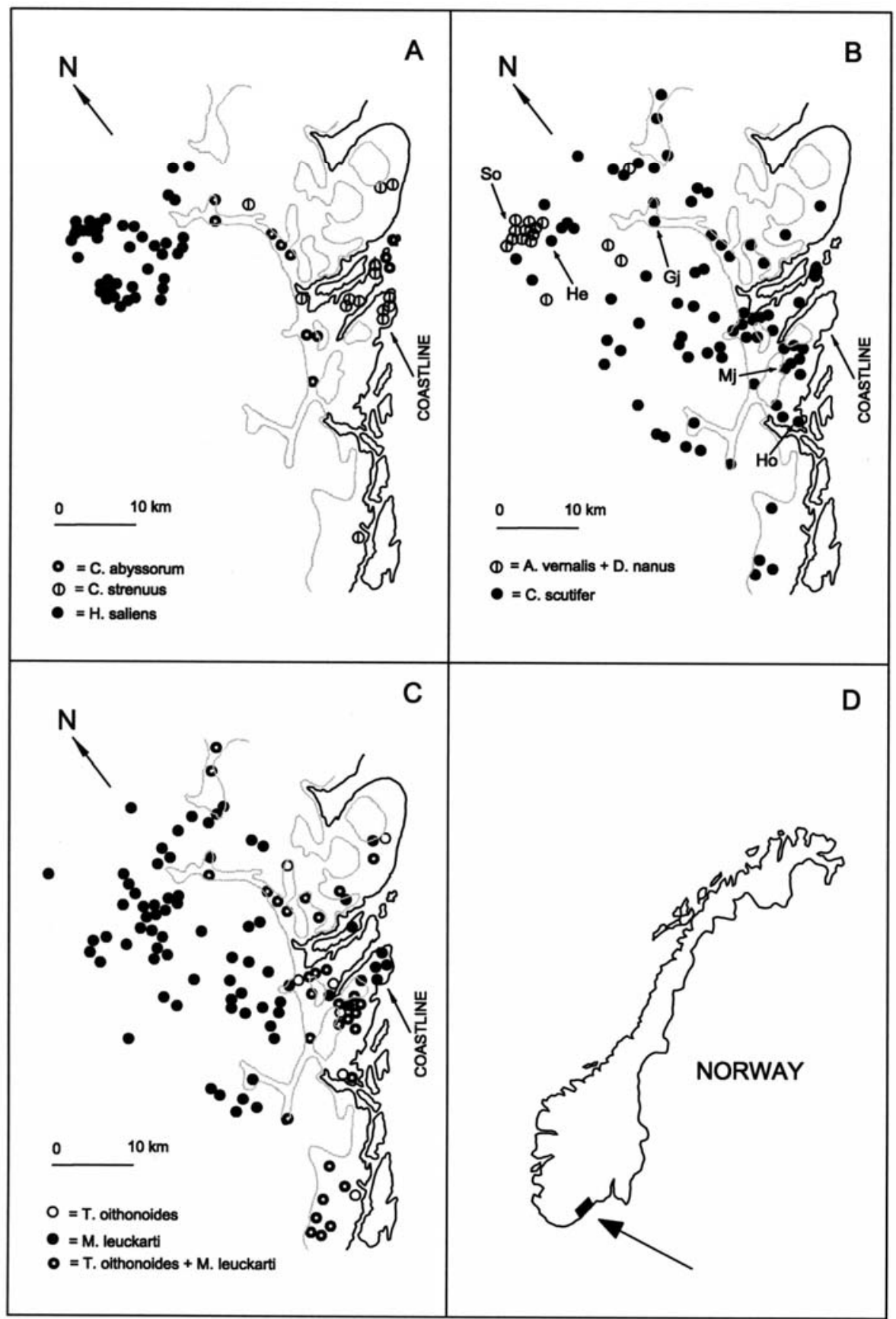

Fig. 2. Distribution of major pelagic copepods $(n=148$ sites) in the investigated region (Fig. 2 A-C) in southern Norway (Fig. 2 D) 1999-2001. Ecological data of the different copepod species are presented in table 1. The former postglacial marine limit is indicated with grey line. The geographical position of the sites in figure 1 is pictured with arrows in figure 2B. So: Solhomfjell lakes, He: Lake Heilandsvann, Gj: Lake Gjerstadvann, Mj: Lake Mjåvann, Ho: Lake Hovdansvann. Most lakes inside of site Gj are chronically acidified, belonging to category A lakes.

acidification took place between 1950 and 1970 (Fig. 1), when $\mathrm{pH}$ dropped from about 5.2-5.4 to 4.5-4.7 (Fig. 1). In such sites the buffering capacity is gone and $\mathrm{pH}$ has stabilised at a level around $\mathrm{pH}=4.4-4.8$ (Fig. 1; Tab. 2). These lakes are primarily situated in the geographically innermost region (inside of site $\mathrm{Gj}$ in Fig. 2B), but also encompasses some few isolated lakes situated on acid bedrocks and shallow Quaternary deposits in more baserich geological areas closer to the coast. Often chronically acidified lakes are being limed, such as Lake Heilandsvann (site 26), and its subsequent $\mathrm{pH}$ development is pictured in figure 1 .

The temporal development of transitions lakes (category B) where the buffering capacity is almost 


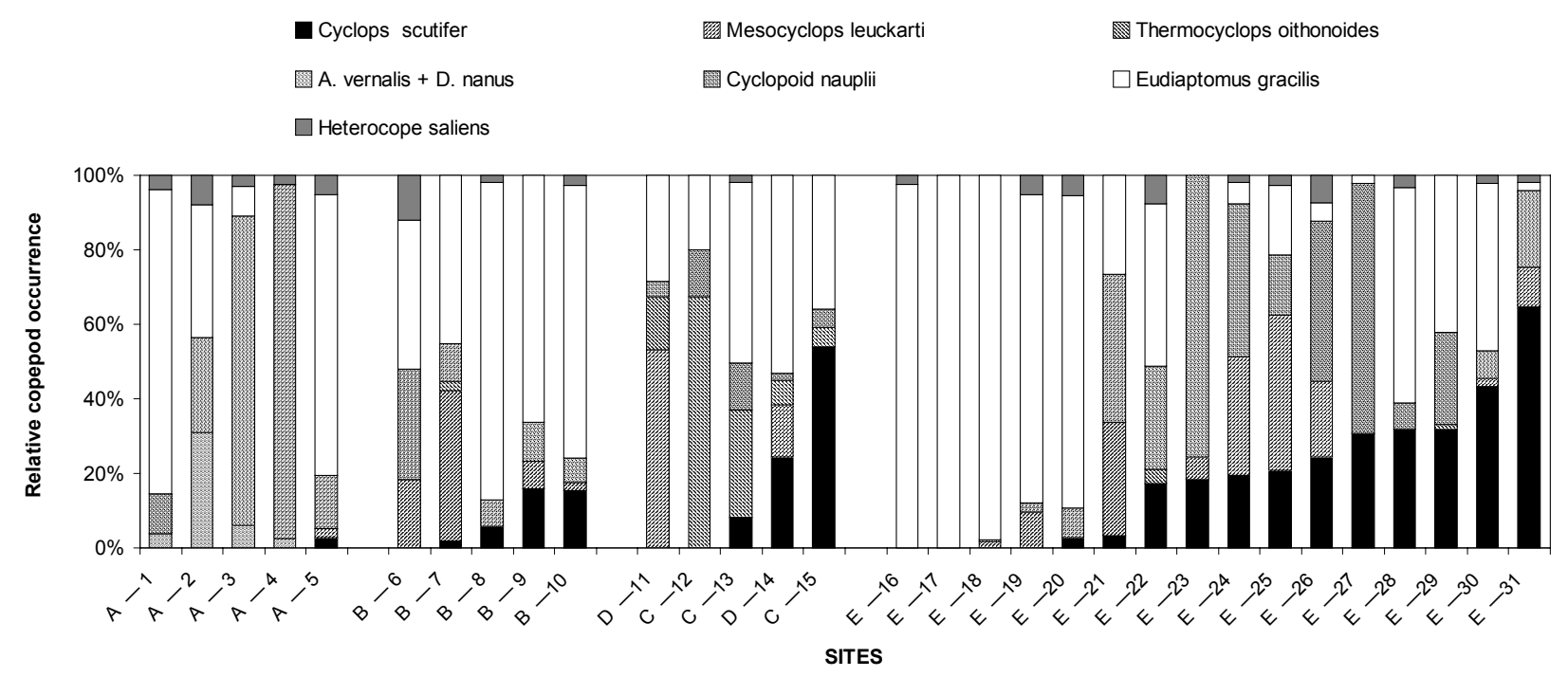

Fig. 3. Pelagic copepod community from the selected sites $(n=31)$ during July-September from 1999 - 2001. Category A-E defined in Methods. Site numbers refer to table 2. Abundance of the predation vulnerable $H$. saliens is probably depending upon a combination of fish planktivory and/or sediment egg-bank density.

gone, $\mathrm{pH}$ strongly fluctuating and low (usually $\mathrm{pH}$ : 4.85.5), is represented by Lake Gjerstadvann (site $\mathrm{Gj}, 7$; Fig. 1; Tab. 2). During the period with major acidification (1970-80), pH decreased below 5.0.

Lakes where the buffering capacity was reduced and the $\mathrm{pH}$ temporarily lowered (category $\mathrm{C}$ ), usually to $\mathrm{pH}$ : 5.3-5.8 during the period with major acidification (1970-80), is represented by Lake Mjåvann (site 12; Fig. 1; Tab. 2). Also in such lakes $\mathrm{pH}$ fluctuated considerably due to decreased buffering capacity and periodically approached $\mathrm{pH}=5.5$.

Lake Hovdansvann (site 14; Fig. 1; Tab. 2) describes a lake with intact buffering capacity (category D) and $\mathrm{pH}$ usually above 6.5. Such lakes are often situated close to the coast and have in addition a history of natural eutrophication due to intense bird droppings, and a few are antropogenic eutrophicated due to agriculture and domestic run-off from the local communities.

The temporal patterns in lake development can also be identified spatially in this area, since the chemical gradient of lakes from the coast inland, encompasses all lake categories described in figure 1 .

The geographical distribution of the dominant planktonic copepods collected in the present study from $1999-2001$ is shown in figure $2(\mathrm{n}=148)$. The calanoid copepods observed were E. gracilis, H. saliens, Mixodiaptomus laciniatus, and the cyclopoid copepods were C. scutifer, M. leuckarti, T. oithonoides, C. strenuus, C. abyssorum, Acanthocyclops vernalis, and Diacyclops nanus. Less than 5 specimens of the calanoid copepod Mixodiaptomus laciniatus were recorded in site 23 where it had probably been spread by gill-net activities associated with fishing (cf. Kaste et al. 1999), and it is excluded in all tables and figures.
The most common species was E. gracilis (87\% of all sites), and its distribution is therefore not shown in figure 2. It was found in all kinds of biotopes, from infrahaline rock-pools $\left(\mathrm{A}_{0}=10 \mathrm{~m}^{2}, \mathrm{Z}_{\mathrm{m}}=0.8 \mathrm{~m}\right)$ to the largest lakes $\left(\mathrm{A}_{0}=18.8 \mathrm{~km}^{2}, \mathrm{Z}_{\mathrm{m}}=110 \mathrm{~m}\right)$, from the highest to the lowest $\mathrm{pH}(\mathrm{pH}=4.2-7.6)$. Another frequent species, $H$. saliens, was restricted to the innermost region (inside of site $\mathrm{Gj}$ ), or to lakes acidified for a considerable period of time, situated on barren rocks throughout the region.

The predominantly benthic and littoral cyclopoid species $A$. vernalis and $D$. nanus were the dominant copepods in the plankton of strongly acidic lakes devoid of other planktonic cyclopoids (Fig. 2B), but seldom formed planktonic populations in other sorts of lakes (Fig. 3). Adults and late copepodids IV-V of these species were very seldom recorded in the pelagial of even the most acidic lakes (Nilssen \& Wærvågen unpubl. data), which indicated that they used the littoral and profundal regions as habitats for later ontogenetic instars.

The two most common cyclopoid species were $C$. scutifer and $M$. leuckarti, found in all parts of the area (Figs 2B, 2C). They were rarely encountered in the most acidic lakes, especially C. scutifer. T. oithonoides and C. strenuus (Figs 2C, 2A) was nearly always recorded below the former postglacial marine limit, and were quite common in the area. The latter was regularly encountered in the less intensively sampled small permanent ponds and small nutrient-rich lakes, its precise distribution is not yet well known. C. abyssorum was abundant in coastal rock-pools subject to considerable salinity ranges, but was also recorded in the hypolimnion in some lakes below the postglacial marine limit, albeit always in very small numbers (Fig. 2A). 
C. scutifer

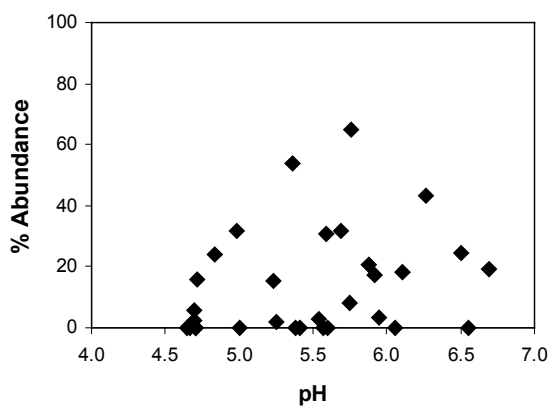

E. gracilis

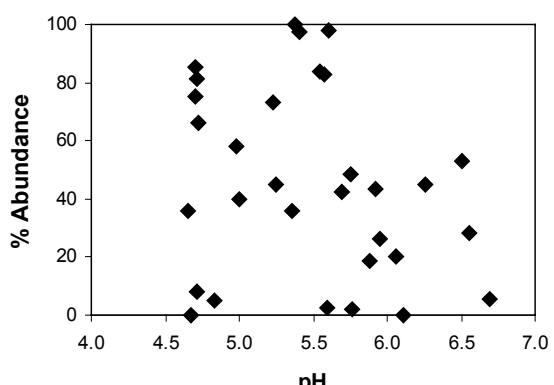

M. leuckarti

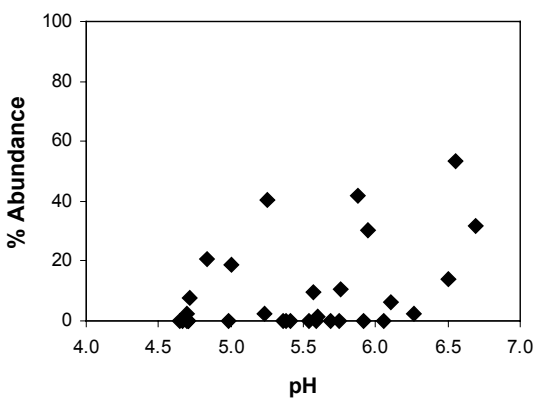

H. saliens

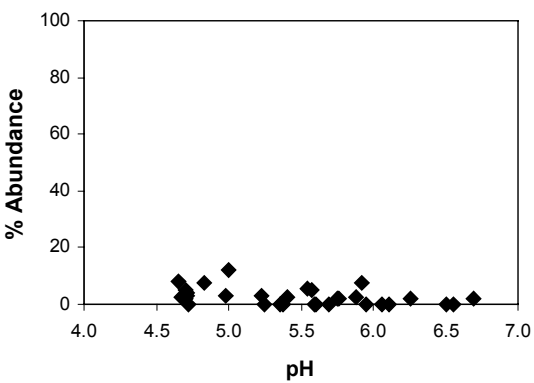

T. oithonoides

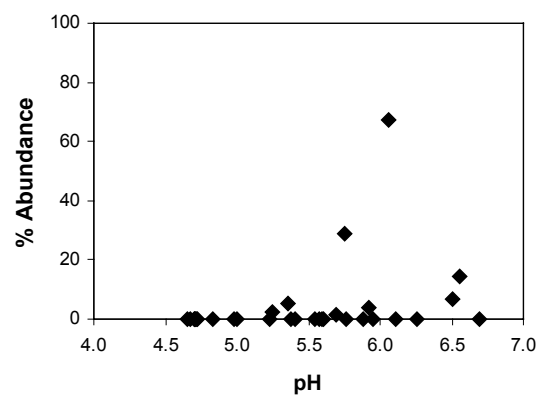

A. vernalis + D. nanus

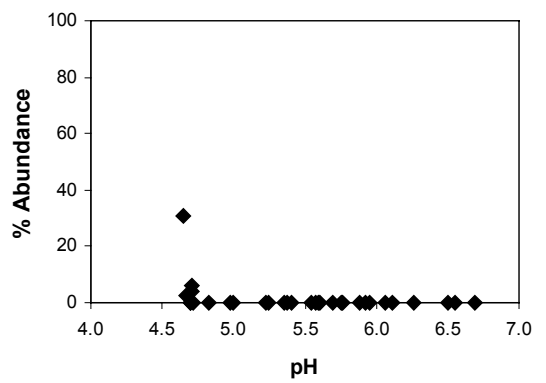

Fig. 4. Relationship between $\mathrm{pH}$ and the different pelagic copepods (percentage species abundance of total copepods). Based on sites presented in figure 3 and table $2(n=31)$. See text for further details.

A selection of the plankton copepod communities ( $\mathrm{n}$ $=31$ ) from the present geographical area shown in figure 2 , is given in figure 3 , encompassing category $\mathrm{A}$ lakes (sites 1-5), category B lakes (sites 6-10), category $\mathrm{C}$ lakes (sites 12-13, 15), category D lakes (sites 11, 14), and category E lakes (sites 16-31). For more information on the sites, see table 2.

The innermost region with category A lakes had a copepod community composed of the calanoids $\mathrm{H}$. saliens, E. gracilis, the cyclopoids A. vernalis, and the less common D. nanus. Another important characteristic was the scarcity of cyclopoid copepods, especially hypolimnetic species, such as $C$. scutifer. The simultaneous absence of $C$. scutifer and presence of $H$. saliens in such lakes provided information of decade-long duration of very low and critical $\mathrm{pH}$, below $\mathrm{pH}=4.6-4.8$.

Some category B lakes had low abundance of $C$. scutifer, whereas other showed higher populations. Shallow sites were generally devoid of the cold water tolerant C. scutifer (sites 11-12). Relatively high populations of the large-size and conspicuously coloured $H$. saliens were indicating low fish planktivory, and found in many categories of lakes, especially categories A and $\mathrm{E}$, when the latter originated from category A before liming. When fish predation was intensive, categories $\mathrm{C}$ and $\mathrm{D}$, the species was rarely encountered. Considerable populations of $C$. scutifer are now recorded in a number of category E lakes (Fig. 3).
The direct relationship between $\mathrm{pH}$ and relative abundance of pelagic copepods is presented in figure 4 . All three cyclopoid species C. scutifer, M. leuckarti, and $T$. oithonoides strongly decreased when $\mathrm{pH}$ approached $\mathrm{pH}=4.5-4.7$, and $A$. vernalis and D. nanus increased. $H$. saliens had low percentage abundance over the whole $\mathrm{pH}$ range, but increased at lower $\mathrm{pH}$. E. gracilis was recorded over the whole $\mathrm{pH}$ range, but showed decreasing abundance above $\mathrm{pH}=5.7$. No significant statistical relationship was found between $\mathrm{pH}$ and single species abundance.

\section{DISCUSSION}

\subsection{Recovery and aquatic community targets}

Knowledge of the recovery of aquatic biota and pelagic copepods from lake acidification is often limited, especially concerning the different temporal rates and pathways of the processes. Serious problems in the interpretation of data also arise due to the current and long-term neglect of taxonomy and autecology within the group. In the present study this mainly concerns the cyclopoid copepods, an important group of freshwater animals (Fryer 1998). In a number of regional studies, pelagic cyclopoids are often referred to as Cyclops spp., irrespective that several genera with a variety of life histories are being included in the category. 
Many approaches are available to set targets for the recovery of ecological communities from acidification. Assuming habitat quality can be restored, the best approach is to use the previously known biotic structure of the site. Unfortunately, such data are scarce for acidified lakes. And if they were, changing and fluctuating taxonomy and nomenclature can often create a hindrance than help in this work. In the present area, limnological data were available from early 1940s (Hauge 1942), but only a few of the most conspicuous species of the zooplankton community were identified at the genus level, with limited relevance to the present work.

Furthermore, since copepods usually leave no paleolimnological records in the sediments (cf. Nilssen 1978a), another appropriate target is a community composed of common species in the area known for their physiological relationship to acidity. In the present area, several common cladocerans have been investigated, but only advanced copepodids and adults of the copepods $C$. abyssorum and $H$. saliens (Nilssen et al. 1984b). One is therefore obliged to use an approach to identify a community typical for non-acidic reference lakes with similar environmental parameters in this area (i.e., size, depth, stratification type, fish and invertebrate predators) and use this as a biological recovery target.

Unfortunately, many parts of Norway suffer a continuous loss of scientifically indispensable reference localities (unlimed or unmanipulated), since local inhabitants tend to lime most sites that easily can be reached by motorised vehicles below a certain altitude. This loss of reference sites makes it increasingly difficult to prove the existence of natural recovery processes, which is of major interest in current community ecology (Keller et al. 1999; Nilssen \& Wærvågen 2001).

Natural communities, as observed in well-buffered lakes in a specific geographical region, may usually be accepted as appropriate recovery targets for the deacidified lakes. It should be added that Norway harbours a variety of natural soft-water acidic lakes, also before acidification started in the most susceptible areas during early 1900 (cf. Snekvik 1974b). For many of these lakes, a more appropriate aim for the liming activities for the common vulnerable fish species would be to keep a $\mathrm{pH}$ between 5.0-6.0, and a calcium concentration at approximately 1-2 $\mathrm{mg} \mathrm{l}^{-1}$. In addition, a selection of sites should be left as reference localities. A relationship between calcium concentration in lakes and zooplankton distribution, as well as potential calcium limitation for selected species have recently been published from Norway (Wærvågen et al. 2002).

The present region offered some unique possibilities: it harboured a variety of lake types with different prehistories due to a contrasting structure of bedrock and Quaternary deposits, it was rich in zooplankton species; many scientists have been working here since the 1970s, and produced a number of theses, scientific reports and publications on terrestrial and aquatic ecosys- tems (see Material and methods). Zooplankton form a very useful group of animals in acidification and recovery studies because many large-scale surveys have allowed the definition of typical community types and community variables relating to biological characteristics during ecosystem development (cf. Keller \& Yan 1998; Nilssen \& Wærvågen 2001; 2002a; 2002b). The detailed zoogeographical and autecological studies within the last 30 years, combined with a thorough knowledge of the liming processes, helps to set the target despite the scarcity of earlier amenable observations. In addition, we maintain that the temporal patterns in species sequences can be deduced by studying the present spatial distribution related to the different lake categories as previously presented.

The relationships of the present copepods to acidification and recovery are shown in figures 2-4. Both physiological and ecological factors influence the copepods during these processes. The direct relationship between $\mathrm{pH}$ and relative abundance of pelagic copepods were presented in figure 4. The "apparent maximum" plot of the different species' abundance forms an envelope most probably indicating the physiological tolerance for the species at specific $\mathrm{pH}$. The actual scattering in the species abundance plot at various $\mathrm{pH}$ indicates, however, influences from different biotic factors such as competition and predation.

All three cyclopoid species C. scutifer, M. leuckarti, and $T$. oithonoides strongly decreased when $\mathrm{pH}$ approached $\mathrm{pH}=4.5-4.7$ (Fig. 4), probably due to physiological factors (Sandøy \& Nilssen 1987b). The predation vulnerable $H$. saliens had low percentage abundance over the whole $\mathrm{pH}$ range. The decreasing percentage abundance of E. gracilis above $\mathrm{pH}=5.7$, most probably arise from competition with the cladoceran Daphnia longispina (Muck \& Lampert 1984; Lampert \& Muck 1985) which increase strongly in that $\mathrm{pH}$ interval following chemical recovery (Nilssen \& Wærvågen 2001; 2002b). These few examples demonstrate that the relation of planktonic copepods towards acidification stress and subsequent recovery, is not a simple cause-effect relationship to changing $\mathrm{pH}$.

\subsection{Copepod species composition in the communities following liming}

4.2.1. Temporal community development, lake stratification and fish predation

The new communities following liming are composed of a complex combination of the existing tolerant community and colonists. These colonists can trace their origin from outside the lake or within the lake. Among the present species, only $H$. saliens possesses an eggbank, whereas the other species are mainly dependant upon residual populations and other ecosystems for their dispersal (cf. Tab. 1).

A considerable liming activity has been carried out in this region of southern Norway from about the early 
1980s until present (Hindar et al. 1998). Since then, several conspicuous changes are observed in the communities: the antropogenic introduction of game fish such as brown trout ( $S$. trutta), the strong numerical increase from small residual populations of Eurasian perch (P. fluviatilis) (Nilssen \& Wærvågen 2002a), and the recent arrival into the lake plankton of the key genus Daphnia (Nilssen \& Wærvågen 2002b).

The changes within the pelagic copepods can be diagrammed as shown in figure 5. Shallow lakes with perch or other planktivorous species, show contrasting recovery pattern than lakes with only brown trout, and shallow lakes behave differently from deep stratified lakes with refugial populations of pelagic copepods.

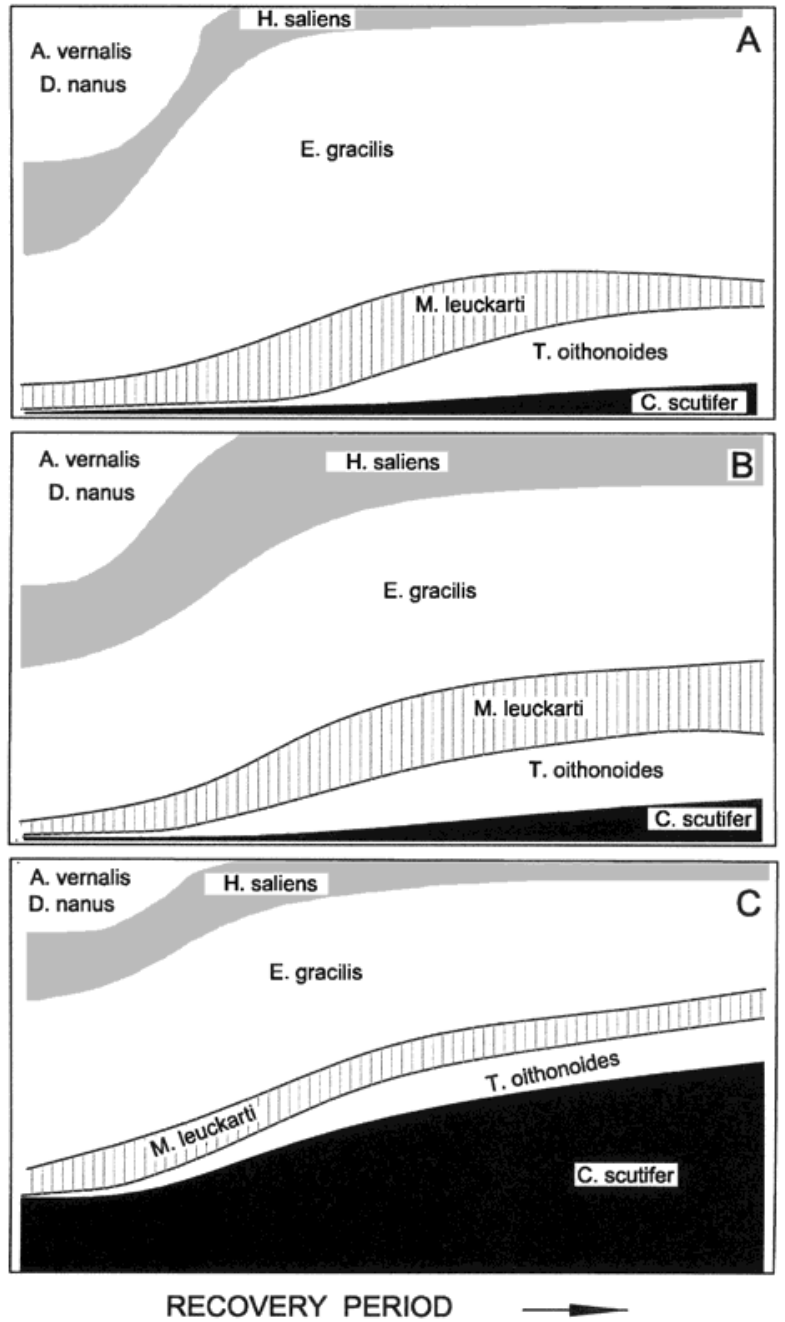

Fig. 5. General sequence of changes in the species composition of major pelagic copepods following recovery from acidification in sites with contrasting fish predation patterns and stratification types. The temporal period on the abscissa is approximately $5-15$ years, depending upon residual populations and intensity of fish planktivory after liming (see Methods and text for details). A: shallow lakes and high fish predation; B: shallow lakes and low fish predation, and C: deep lakes.
Three different pelagic copepod communities can be identified (Fig. 5A-C) based on analysis of all investigated lakes during 1999-2001. These communities are related to fish species and their degree of planktivory, and stratification types according to the classification given by Hutchinson (1957). There are major differences in the new communities following liming if the locality is shallow or deep and stratified with a hypolimnetic temperature during all seasons close to $4{ }^{\circ} \mathrm{C}$ (stratification type I; Hutchinson 1957). Stratification type I encompasses lakes deeper than 15-20 meters and moderately exposed to wind in this area (Fig. 5C). The other lake-type, so-called stratification type II (Hutchinson 1957), exhibits higher hypolimnion temperatures from $7-12{ }^{\circ} \mathrm{C}$, and a maximum depth usually $<15$ m (Fig. 5A-B). Within the last stratification type, a division is made between lakes with brown trout as sole fish species (Fig. 5B), and lakes with efficient planktivorous fish, such as Eurasian perch (Fig. 5A). It is commonly observed that even if lakes have been acidified for several decades, they still harbour some few specimens of large and old perch, originating from earlier successful reproductions following short-duration climatic improvements during spring and early summer periods. Following liming, these old perch reproduce and a lot of underyearlings immediately influence the whole pelagic ecosystem by intensive size-selective predation (Nilssen \& Wærvågen 2002a).

In lakes with brown trout present in small populations or implanted brown trout, E. gracilis increased its prevalence, especially before its major competitor $D$. longispina build up considerable populations (Nilssen \& Wærvågen 2001; 2002b). The littoral species D. nanus and $A$. vernalis disappeared from the pelagial shortly after liming in all lakes. Within a short time-period the epilimnetic species $M$. leuckarti and T. oithonoides increased and lastly the hypolimnetic species $C$. scutifer increased slowly (Fig. 5). With stronger fish predation from Eurasian perch (Fig. 5A), generally the same pattern of development was repeated, but $H$. saliens was found in lower abundance, often being totally absent from the pelagic zone. In the epilimnion, $T$. oithonoides increased relatively to $M$. leuckarti, probably due to fish predation on the latter (Nilssen \& Wærvågen 2000). $C$. scutifer has a partly hypolimnetic refuge from fish predation in some lakes. However, under strong fish predation, because adult females often inhabit epilimnion (Wærvågen 1985; Skov 1985; Nilssen unpubl. data), this species may decrease its abundance as well. Deeper lakes exhibited contrasting development patterns from shallower ones (Fig. 5C). Since considerable populations of $C$. scutifer have avoided strong decimation in these environments by having a hypolimnetic refuge, this species re-populates and dominates the whole pelagial after a few years (Figs 3, 5). 


\subsubsection{Typical pelagic cyclopoid species and their ecological relationships}

Strongly acidic lakes often have species originally restricted to the littoral zone, like $A$. vernalis and $D$. nanus, as prominent inhabitants of the pelagic zone. These two species were only distributed in a few of the lakes in the present area (Figs 2B, 4). D. nanus is a small species usually found in the littoral region of slightly acidic lakes (Lowndes 1952; Jørgensen 1972; Fryer \& Forshaw 1979; Nilssen 1980; Raddum et al. 1986; Walseng \& Hansen 1994). In strongly acidic environments it may also inhabit the pelagic zone (Fig. 3). A. vernalis, very laborious to separate from its near-related species A. robustus (Kiefer 1976; Fryer 1985), is known for its ability to colonise even strongly acidic environments (Lowndes 1952; Fryer 1980; 1985; Yan \& Dillon 1984; Walseng \& Hansen 1994). A. vernalis was described as the most acid-tolerant of the cyclopoid copepods indigenous to the Canadian Precambrian Shield (Yan \& Lafrance 1984; Yan \& Welbourn 1990). Even if it occurred in the most acidic lakes ( $\mathrm{pH}$ around 4.5), it nevertheless reached maximum relative abundance in the most nutrient-rich lakes (Yan \& Lafrance 1984; Yan \& Welbourn 1990). A. vernalis increased strongly in numbers following nutrient additions to enclosures placed in an acidic lake in the present area (Brettum et al. 1984), which supports its great adaptability to thrive also under nutrient-rich conditions. After liming an acidified lake, the species nearly disappeared, but increased its abundance when the locality became reacidified (Yan \& Dillon 1984). Fryer (1985) considered A. vernalis an adaptable, opportunistic species capable of living in the littoral region of large and small waterbodies of many kinds, but it could also select barren, vegetationless habitats, as in the present study (Fig. 3, Tab. 1). Adults of $A$. vernalis and $D$. nanus were never recorded in the pelagial, probably because they spend considerable periods in the littoral and benthic zones. Both species were active during summer and carried only subitaneous eggs, with $A$. vernalis as the most fecund related to body weight (Nilssen \& Wærvågen unpubl. data).

The cyclopoid species $C$. strenuus (Figs 2A, 3, Tab. 1 ) is common and may, like $A$. vernalis, tolerate considerable acidity down to below $\mathrm{pH}=4.0$ (Skadovsky 1926; Lowndes 1952; Herbst 1968; Bērziņš \& Bertilsson 1990). Similar to A. vernalis, C. strenuus can also thrive in eutrophic environments (Elgmork 1959; Einsle 1975). In the present area it was seldom recorded above the postglacial marine limit (Fig. 2A), and was mainly observed in small-sized perennial localities closer to the sea. The species is usually active from the autumn until mid June, when it enters summer diapause. It produces 1-3 generation per year, usually two in ponds and one in lakes (Elgmork 1959; Næss \& Nilssen 1991). It has a lot of small, subitaneous eggs (Maier 1994).
Although Fryer \& Forshaw (1979) recorded C. abyssorum on the British Isles under strongly acidic environments, this is not common for the species, which usually inhabits slightly acidic to slightly alkaline environments (Lowndes 1952; Nilssen \& Elgmork 1977). It is moreover abundant as the only cyclopoid in coastal rock-pools (Nilssen \& Stene in prep). The species is distributed in slightly acidic lakes $(\mathrm{pH}=5.0-6.5)$, and always in the hypolimnion (Tab. 1)(Nilssen unpubl. data). It produces 1-2 generations per year, carrying few, subitaneous eggs (Maier 1994). Both C. strenuus and $C$. abyssorum are uncommon in strongly acidified lakes in the present area, and are not yet recorded from the innermost, strongly acidic region before liming (Fig. 2A).

A similar distributional pattern, as with the two former species, was registered for the epilimnetic $T$. oithonoides (Figs 2C, 3). It was seldom recorded above the postglacial limit, and rarely recorded from acidic sites during the most acidic period, but showed increasing abundance following decreasing acidity associated with liming (Fig. 5, Tab. 1). It is a summer active species, producing 2-3 annual generations and a few, large-sized eggs (Lacroix \& Lescher-Moutoué 1984; Næss et al. 1993; Nilssen \& Wærvågen 2000).

The hypolimnetic C. scutifer was sensitive to strong and permanent acidification, and disappeared altogether following acidification from shallower localities (Figs 4, 5). It was distributed in many localities in the present area, except for the most acidic and most shallow lakes $(<5 \mathrm{~m}$ ), and temporal and perennial ponds (Fig. 2B, Tab. 1). In deeper sites it seems able to have higher population densities, probably due to the more stable and slightly higher $\mathrm{pH}$ in hypolimnion. The species is perennial in the region, produces $1 / 2$ to 1 generation yearly, and a medium clutch size with subitaneous eggs only (Tab. 1) (Wærvågen 1985; Skov 1985; Nilssen unpubl. data).

The least sensitive of the typical pelagic cyclopoid species is $M$. leuckarti, recorded in all sorts of localities aside of the smallest ponds and the most acidic lakes (Figs 2C, 4, 5; Tab. 1). The species is distributed in the epilimnion, exhibits winter diapause in cop IV-V, produces 2-3 generations a year, with medium-large clutch sizes (Nilssen \& Wærvågen 2000).

The low abundance of many species, especially the typical pelagic cyclopoid copepods in acidic lakes, is probably caused by disturbances in the egg production phase or during early naupliar stages (Skadovsky 1926; Sandøy \& Nilssen 1987b).

\subsubsection{Typical pelagic calanoid species and their ecological relationships}

E. gracilis is the only species of calanoid copepods commonly recorded in this study that filters algae, bacteria and probably protozoa (see Lair \& Hilal 1992; Adrian \& Schneider 1999). It is able to withstand con- 
siderable acidic environments, and is found in nearly all types of localities. Usually it is recorded below an altitude of $1000 \mathrm{~m}$ in Norway (Walseng \& Halvorsen 1993). It produces 1-4 generations a year, is perennial and has only subitaneous eggs (Santer et al. 2000). Clutch size is correlated with the trophy of the locality (Czeczuga 1960). It remains to be shown that E. gracilis winters in some sort of plankton diapause (so-called "active diapause"), which has been suggested for several cyclopoid (Halvorsen \& Elgmork 1976; Elgmork 1980) and calanoid copepods (Santer et al. 2000).

H. saliens (Figs 2A, 3, 4; Tab. 1) is the only predominant carnivorous calanoid copepod in southern Norway (Nilssen 1980; Walseng \& Halvorsen 1993), and occurs frequently under conditions of high acidity and low fish predation pressure (Eie 1974; Hobæk \& Raddum 1980; Nilssen 1980). The entire genus in Scandinavia is vulnerable to fish predators and have developed strategies to decrease the impact of such predation (Andersen \& Nilssen 1984). H. saliens produces only one yearly generation, and is summer-active. It has a true egg-bank in the sediment (Sandøy \& Nilssen 1987a), which implies it has both an annual winter diapause and delayed-hatching egg reservoir in the sediment (cf. Chen \& Marcus 1997). Often the adults live for extended periods during summer and autumn producing exclusively resting eggs of the two types, which immediately sink to the bottom.

All copepod species studied, except for $H$. saliens, produce subitaneous eggs only, carried in one or two egg sacs attached to the genital segment. This strategy avoids the transport of sensitive subitaneous eggs into the littoral or profundal sediments, which is detrimental for such type of eggs (cf. Uye 2000). This egg-carrying strategy makes pelagic species vulnerable to predation by visual predators such as fish (Winfield \& Townsend 1983; Svensson 1997), but in addition adult copepods are also visible during some part of their oovigerous cycle, especially when oocytes are mature (cf. Maier 1992). Some species have developed strategies to decrease this predation. Adults of $M$. leuckarti stay mainly in the littoral (Nilssen \& Wærvågen 2000), which also may be the case for $A$. vernalis, when fish are present.

\subsubsection{Pelagic copepod communities in other acidified regions}

Recovery of acidified lakes is not yet a common research field in Scandinavia, with some notable exceptions, however: Lake Gårdsjön in Sweden, and the Swedish and the Norwegian liming research projects. In Lake Gårdsjön, liming started already in 1981. Studies were carried out some years before fish were introduced; first the medium planktivorous brown trout, and then the voracious rainbow trout (Oncorhynchus mykiss). The careful long-term study of Lake Gårdsjön, has accumulated much of the knowledge on recovery of such Scandinavian lakes. The copepods were not specifically studied, however, and the species reported throughout the acidification and liming history were mainly $T$. oithonoides, $C$. abyssorum and E. gracilis. The acid-tolerant $C$. strenuus unusually increased after liming following the introduction of fish (Stenson \& Svensson 1994). However, cyclopoid copepods showed very low abundance during the whole liming and pre-liming period, and it may be hypothesised if this important species group has yet recovered from acidification in Lake Gårdsjön (cf. Fig. 5). E. gracilis was very common through the whole history of these strongly variable environmental conditions. It is known to consume large species of phytoplankton and ciliates and is able to live on Peridinium umbonatum (= inconspicuum) and Dinobryon sociale var. americanum, which were common species in most lakes during the acidification phase (Svensson et al. 1995). This apparent insensitivity of $E$. gracilis towards considerable environmental stress, underscore the importance of further and more detailed ecological studies on the autecology of this species (cf. Svensson 1996; Santer et al. 2000).

Similar findings were reported from other Swedish liming projects; E. gracilis was not markedly influenced by any of the manipulations, small amount of cyclopoids were recorded before the liming and showed increased population abundances afterwards. Cyclopoids were commonly identified as Cyclops spp. (Eriksson et al. 1983; Hörnström et al. 1993; Appelberg 1995a), or in some few cases identified at the species level as $C$. scutifer (Appelberg 1995b). In southeastern Norway, $C$. scutifer also seems to increase in limed lakes after a certain period (Walseng \& Hansen 1994; Walseng \& Karlsen 1997; Nilssen \& Wærvågen 2001).

The relationship between cyclopoids and calanoids could also be due to the different food requirements of their nauplii. Nauplii of copepods are developmental bottlenecks (Santer 1994; Santer \& Lampert 1995), but threshold food concentrations are lower for calanoid (here E. gracilis) than cyclopoid copepods (Santer 1994), which could lead to a competitive advantage for E. gracilis in such low food environments as the acidic lakes. In addition, E. gracilis produces through its feeding behaviour even more oligotrophic environments. By dropping relatively insoluble faecal pellets which accumulate rapidly in the sediments (Nyman 1990), it can drain the pelagic zone of nutrients, and produce a competitive advantage over the other copepods. Nassal et al. (1998) found that cyclopoid copepods were significantly more heavily preyed upon by fish than the calanoids (in this case also E. gracilis). The above-mentioned factors give E. gracilis several ecological advantages in harsh environmental conditions. Even when acidification and fish predation change considerably, it undergoes minor changes in relative abundance (Fig. 5).

In low-buffered lakes in Ontario, Canada, most pelagic copepods decreased considerably following acidi- 
fication (Carter et al. 1986). Keller et al. (1992) reported that acid-sensitive species such as Epischura lacustris and Skistodiaptomus oregonensis were absent in a chronically acidified lake, near Sudbury, Canada. Four years after the experimental neutralization of the lake, E. lacustris was found to be important in the plankton (Keller et al. 1992). In other Ontario lakes, declines in abundance of the acid-sensitive species, such as E. lacustris and $S$. oregonensis resulted in increases in other acid tolerant species (Sprules 1975a; 1975b; Marmorek \& Korman 1993). In some of the industrially acidified lakes with $\mathrm{pH}$ below 5.0 in the La Cloche Mountains, Canada, Leptodiaptomus minutus was the only zooplankton species found, a very unusual community structure for a temperate lake (Sprules 1975a; 1975b). Pelagic copepods typical for acidic systems in the Sudbury region, Canada, were above all L. minutus, but also Diacyclops thomasi and Mesocyclops edax tolerated acid environments (Keller \& Yan 1998). Following chemical recovery, $S$. oregonensis, E. lacustris and Tropocyclops extensus showed increased abundance, whereas the hypolimnetic $C$. scutifer was rarely observed to colonise lakes from which it was initially absent (Keller \& Yan 1998).

\subsection{Severity of acidic stress and recovery}

Considering the different communities observed during liming in the present zoogeographical region, most of the zooplankton species could be used, alone and in combination, as community indicators to identify the severity and duration of former acidic stress (Figs 4, 5). A large number of factors influence the rate of recovery of biota from earlier acidification. These factors include the severity, duration and timing of stress, the time since its removal, and the condition of the community before de-acidification started. It is also depending upon the availability of refuges, the distance of sources of potential colonists or species-bank, the barriers to their dispersal and successful colonisation, and the life histories and dispersal abilities of the organisms (Niemi et al. 1991; Nilssen \& Wærvågen 2002b).

The present geographical region encompasses sites with very differing acidification histories due to contrasting bedrock and Quaternary deposits. Acidification in this part of Scandinavia started already during early 1900 with local, restricted acidification episodes (cf. Snekvik 1974b). The copepod community typical of the most acid lakes is shown in figure 3 (lake category A), where littoral species and $H$. saliens are conspicuous members of the community. But on the other hand, acid-tolerant species such as E. gracilis and M. leuckarti are more seldom encountered here. $M$. leuckarti is rare because of the strong acidity $(\mathrm{pH}$ very seldom above 4.8 ), but $E$. gracilis does not normally suffer problems due to the acidification in these lakes (around $\mathrm{pH}=4.5$ ). A conspicuous trait in the most acidic lakes in this area, is the profuse growth of green filamentous algae (see
Jackson et al. 1990), usually of the groups Zygogonium spp. and Mugeotia spp. (Brandrud et al. 1999). They cover the littoral zone and close to bottom areas in all these localities, and most such localities down to $2 \mathrm{~m}$ depth in shallow water bodies $(<4 \mathrm{~m}$; Nilssen 1980, unpubl. data). A large part of this filamentous algal mass drifts across the water body following only small changes in currents and wind patterns (cf. Almer et al. 1974). These loosely attached algal clouds, so-called "metaphyton", partly clogged net samples in such lakes, even those drawn through the pelagial zone. Metaphyton probably exerts a strong influence upon specialist filter feeders as E. gracilis, and the scarcity of this euryoecous species in such environments could be due to filter-feeding inhibition by filamentous algae. Correspondingly, E. gracilis was also extremely scarce in vegetation dominated littoral systems in all categories of lakes in the present area (Nilssen \& Wærvågen unpubl. data). Following liming, metaphyton disappeared after some months or within the first year (Brandrud et al. 1999), and E. gracilis also increased rapidly in such systems.

Few studies are available following liming of chronically acidified lakes in Scandinavia, such as in the present region (Fig. 3, lake category A). Superficially, Lake Gårdsjön may be considered as one lake belonging to this group, but several characteristic species were not present here, such as $H$. saliens and some of the littoral ones. There are additional observations which indicate that many southern Norwegian inland sites were subject to acidification much earlier than most Swedish sites, and have also been affected over a considerably longer period of time (cf. Snekvik 1974b; Nilssen 1980; Morling \& Pejler 1990). Morling \& Pejler (1990) presented a classical study of selected West Swedish lakes reporting significant acidification from a $\mathrm{pH}$ close to 7.0 in 1960 to about $\mathrm{pH}=4.5,15$ years later. By 1960 the innermost situated lakes in southern Norway, had already endured a $\mathrm{pH}$ around 4.5-4.8 for several years (cf. Fig. 1). Thus, the Norwegian lakes were probably strongly affected even since the late 1940s, following the industrial build-up in Europe after the Second World War. This agrees well with the fish-catch information from local fishermen, because fish die-out already started in the early 1950s in many regions (Snekvik 1974a).

Lakes in the innermost region have probably harboured the present zooplankton communities for at least half a century or longer (Nilssen 1980; cf. Figs 2, 4). Liming such chronically acidified lakes has earlier been performed in Norway, with e.g. Lake Hovvatn $\left(Z_{m}=20\right.$ m) (Raddum et al. 1986). Although mainly reporting on the cladocerans, the copepods either disappeared due to fish predation (the large-sized H. saliens) or abundance continued as before liming (as with $E$. gracilis; Raddum et al. unpubl. data). After about 20 years of liming, no cyclopoid copepod was reported in the pelagic zone of 
Lake Hovvatn (Brandrud et al. 1999), which has been ascribed lack of suitable refuges for species in this area, where pelagic cyclopoids are generally very scarce due to the chronic acidification. However, considerable populations of $C$. scutifer and $C$. abyssorum are now (July 2002) observed in Lake Hovvatn (Nilssen unpubl. data). It is a relatively common phenomenon that $C$. abyssorum inhabits the pelagial during early recovery of formerly chronically acidified lakes as a fugitive species (Nilssen unpubl. data), probably due to rapid dispersal. In the present chronically acidified area, the few limed lakes have correspondingly few pelagic cyclopoids, except for the deepest lakes that harbour residual populations of $C$. scutifer in hypolimnion. Nilssen \& Sandøy (1986) have earlier stressed the importance of deep-water refuges, since hypolimnetic $\mathrm{pH}$ frequently differs by nearly one $\mathrm{pH}$ unit from conditions in the epilimnetic waters in many acidified Norwegian lakes (Hindar \& Nilssen 1984).

It is thus feasible to reveal sites that have been chronically acidified for many decades by observing the frequent loss of some and prosperousness of other species groups, using selected bioindicators within copepods (this study), cladocerans (Nilssen \& Wærvågen 2002b), and rotifers (Wærvågen \& Nilssen 2003). Loss of species especially concerns groups with negligible dispersal capacities, because they are commonly distributed in the hypolimnion, or have no apparent refuge populations close to the investigated sites.

\subsection{Internal community resistance: invertebrate and vertebrate predators during acidification and recovery}

Changes in fish populations are likely to exert profound effects on the restructuring of aquatic communities following chemical recovery. In fishless lakes, an abundance of invertebrate predators, such as larvae of Chaoborus and Corixidae, both preferred fish prey, may prevent re-establishment of "normal" communities even after suitable water quality improvements. When a species is spread to a limed locality, it does not necessarily imply that it will re-establish a population there. Both invertebrate and fish predators are biological constraints to species distribution in the present area, and act as internal community resistance.

The different species investigated in the present study involves a whole array of life histories from eggbanks to perennial occurrences without sediment diapause. The large, predatory $H$. saliens and other Heterocope species will strongly influence the biota, especially in smaller biotopes without fish. $H$. saliens was able to simplify the whole alpine ecosystem structure in small environments (Burckhardt 1944), and it would readily consume juvenile $B$. longispina, while ignoring juvenile $H$. gibberum and D. longsispina (Hessen 1990). Monakov (1972) found it would consume a variety of small cladocerans and copepods, but predation by $H$. saliens is probably not generally responsible for the low abundance of cyclopoid copepods in acidic lakes (cf. Sandøy \& Nilssen 1987b). The smaller species H. appendiculata which, in contrast to $H$. saliens, disappears due to low $\mathrm{pH}$ in acidic localities, showed higher clearance rates on juvenile $C$. scutifer than on juveniles of the calanoid Arctodiaptomus laticeps, the two prey tested (Grossnickle \& Næsje 1993). The larger NorthAmerican congener $H$. septentrionalis was, like $H$. saliens, able to control species composition in similar sites in arctic ponds (Hebert \& Loaring 1980; Luecke \& O'Brien 1983). All authors agree that H. saliens is unable to consume large-sized Daphnia (Burckhardt 1944; Hebert \& Loaring 1980; Luecke \& O’Brien 1983; Nilssen et al. 1984a). These somewhat fragmentary observations on Heterocope food items and predation suggest that it could in the most acidic lakes largely influence most of the pelagic and littoral communities (cf. Fig. 3), but probably not drive single species to extinction. The detailed and combined effect of $H$. saliens on the plankton community is, however, not yet known. The continuous presence of $H$. saliens after liming, even in lakes with planktivorous brown trout, is probably due to the appearance of delayed-hatching egg from the sediment egg-bank in such localities (Sandøy \& Nilssen 1987a). As the recruitment to this egg-bank decreases over time, the abundance of $H$. saliens in the pelagial zone of limed lakes will also decrease. Omnivorous cyclopoid copepods, that become increasingly more carnivorous throughout their ontogenetic development, and increasing body-size, are probably much less influential on the total zooplankton community than H. saliens (cf. Nilssen 1978b). However, copepods are not the major predators in these lakes, but insects like larvae of Chaoborus spp. and different species of Corixidae (Stenson et al. 1993).

When fish are spread or introduced to an existing community and become key predators, these relations are turned nearly upside-down. Both invertebrate predator groups (Corixidae, Chaoborus larvae) are strongly selected prey by fish (Raddum et al. 1979; Eriksson et al. 1983). Within a very short period of time these groups are eliminated by fish, within few weeks for corixids (Oscarson 1986), and slightly longer period for larvae of Chaoborus spp. (Brett 1989). This elimination period was dependent upon the presence of refuges, like an oxygen-free hypolimnion allowing for a considerable Chaoborus population (cf. Stenson \& Svensson 1994).

After fish have eliminated the former invertebrate key-predators, zooplankton like Diaphanosoma, Holopedium, Daphnia spp. and Cyclops spp. slowly reappear in the pelagial region of the limed lakes. It thus seems as the immigration and presence of fish is a necessary condition for the increase in numbers of the above zooplankton species (Stenson \& Svensson 1994). Competition between these zooplankton has been stud- 
ied by several authors. The earlier dominating species $E$. gracilis is now faced with the efficient filter-feeder genus Daphnia spp. Competition is probably keen between these species (Muck \& Lampert 1984; Lampert \& Muck 1985), since they in addition both occupy the upper water layers. Both species exhibit similar efficiencies in collecting particles at low food concentrations, but Daphnia spp. has a competitive advantage at higher food concentrations (Muck \& Lampert 1984; Lampert $\&$ Muck 1985; Gulati 1984). The outcome of this competition seemed to be that the acid-tolerant species $E$. gracilis re-occupies a former, more restricted habitat in the lakes after some period (cf. Fig. 4).

In a detailed investigation over several years in two acidic lakes, it was found that most species belonging to the present zoogeography was recorded in the pelagial and/or littoral zone over the accumulated years, even if they were registered in very inferior numbers (Nilssen unpubl. data). The most acid lake $(\mathrm{pH}=4.2-4.6)$ harboured a very small population both of $C$. scutifer and M. leuckarti, even if most of the eggs produced annually probably did not hatch due to physiological stress by too acid water (cf. Sandøy \& Nilssen 1987b). The revival of the two species in this lake probably derives from their own residual populations. This is probably the case with most cyclopoid copepods in the region. Also Keller \& Yan (1998) stress the importance of small residual populations in the recovery process.

However, some chronically acidified lakes may have completely lost their cyclopoids (e.g. Lake Ljosvann, Lake Kvernsmyrtjenn; sites 16, 17 in Fig. 3), or cyclopoid copepods are found in very small numbers (sites 18-21 in Fig. 3), even if the lakes have been limed for more than 15 years. Other sites may harbour the fugitive species $C$. abyssorum with rapid dispersal capacities following liming. When cyclopoid copepods are not present, they can be spread through feathers of birds and through fish intestines (Gliwicz 1967; Gliwicz \& Rowan 1984; Maier 1990). The copepods, especially females with egg-sacs, frequently accumulate in the shallow water (Einsle 1972) where dabbling ducks often feed. Even in the otherwise hypolimnetic distributed species C. scutifer, a short egg-bearing period in the epilimnion (cf. Skov 1985; Wærvågen 1985) may facilitate dispersal.

\section{CONCLUSIONS}

A number of common calanoid and cyclopoid copepods with contrasting life histories are distributed in this study area of Norway. Copepods are ecologically affected by the acidification and recovery processes, which include numerous abiotic and biotic changes. The most important of these are the chemical changes associated with increased recovery-pH, and community-resistant factors associated with fish and invertebrate predation.
The changes in lakes after acidification stress can be summarised as follows: the littoral/pelagic species withdraw into their original littoral sites, $H$. saliens is still present due to its long-term build-up of resting eggs in the sediment, the other cyclopoids mainly derive from very small, residual populations, probably within each single lake. Summer-active epilimnetic species such as $M$. leuckarti and $T$. oithonoides are probably relatively easily dispersed, and react positively and rapidly to chemical recovery, as well as the only species with an egg-bank structure, $H$. saliens. The typical hypolimnetic species $C$. scutifer is met with serious dispersal problems due to its distribution in the hypolimnion most of the year, and only deep lakes with considerable populations of the species recover rapidly and easily. When $C$. scutifer and other cyclopoid copepods are absent from recent limed lakes, a fugitive species $C$. abyssorum often occurs until the dominant species $C$. scutifer again establishes large populations.

\section{ACKNOWLEDGMENTS}

This paper is a contribution from the research group "Basic science in ecosystem stress and recovery" at the AbelCentre, Gjerstad, South Norway. We are grateful to Gunnar Halvorsen and Bjørn Walseng for useful discussions, Uli Einsle and Maria Holynska for checking copepod samples, Robert C. Wilson for proof-reading the manuscript, and Svein Thorsen for sharing his knowledge and help using AutoCad. The major part of the historical $\mathrm{pH}$ measurements for Lake Hovdansvann and Lake Mjåvann (1971-1988) derive from unpubl. data of the late Toralf Taraldsen, Tvedestrand, S. Norway.

\section{REFERENCES}

Adrian, R. \& B. Schneider-Olt. 1999. Top-down effects of crustacean zooplankton on pelagic microorganisms in a mesotrophic lake. J. Plankton Res., 21: 2175-2190.

Almer, B., W. Dickson, C. Ekström, E. Hörnström \& U. Miller. 1974. Effects of acidification of Swedish lakes. Ambio, 3: 30-36.

Andersen, R. \& J.P. Nilssen. 1984. Mechanisms of co-existence of Heterocope saliens (Crustacea, Copepoda) and planktivorous fish. Fauna nor. Ser. A, 5: 31-36.

Appelberg, M. 1995a. Liming strategies and effects: the Lake Stora Härsjön study. In: Henrikson, L. \& Y.V. Brodin (Eds), Liming of acidified surface waters. Springer Verlag, Berlin: 339-351.

Appelberg, M. 1995b. Liming strategies and effects: the Lake Gyslättasjön case study. In: Henrikson, L. \& Y.V. Brodin (Eds), Liming of acidified surface waters. Springer Verlag, Berlin: 353-361.

Battarbee, R.W., J. Mason, I. Renberg \& J.F. Talling (Eds). 1990. Paleolimnology and lake acidification. Phil. Trans. R. Soc. London, B 327: 223-445.

Bērziņšs, B. \& J. Bertilsson. 1990. Occurrence of limnic microcrustaceans in relation to $\mathrm{pH}$ and humic content in Swedish water bodies. Hydrobiologia, 199: 65-71.

Brandrud, T.E., G. Halvorsen, E.-A. Lindstrøm, G.G. Raddum, P. Brettum, D. Dolmen, G.A. Halvorsen, Ø.A. Schnell, S.-E. Sloreid \& B. Walseng. 1999. Effekter av kalkning på biologisk mangfold. Basisundersøkelser $i$ 
Tovdalsvassdraget 1995-96. DN Utredning 1999/9: 1-126 (Mimeogr. in Norwegian, abstract in English).

Brett, M.T. 1989. Zooplankton communities and acidification processes (a review). Water Air Soil Pollut., 44: 387-414.

Brettum, P., F. Kroglund, J.P. Nilssen, S. Sandøy, A. Skov \& S.B. Wærvågen. 1984. Eksperimentelle innhegningsforsøk $i$ Gjerstad, Aust-Agder. Et forsøk på alternativ behandling av sure vann. Rep. Norw. Liming Project, 16-1984: 1-78 (Mimeogr. in Norwegian).

Burckhardt, G. 1944. Verarmnung des Planktons in kleinen Seen durch Heterocope. Schweiz. Z. Hydrol., 10: 121-124.

Carter, J.C.H., M.J. Dadswell, J.C. Roff \& W.G. Sprules. 1986. Limnetic zooplankton assemblages in Atlantic Canada with special reference to acidification. Can. J. Fish. aquat. Sci., 43: 444-456.

Chen, F. \& N.H. Marcus. 1997. Subitaneous, diapause, and delayed-hatching eggs of planktonic copepods from the northern Gulf of Mexico: morphology and hatching success. Mar. Biol., 127: 587-597.

Czeczuga, B. 1960. Changes in fertility of some representatives of the zooplankton. I. Crustacea from the Rajgrodzkie lakes. Pol. Arch. Hydrobiol., 7: 61-91 (in Polish, summary in English).

Eie, J.A. 1974. A comparative study of the crustacean communities in forest and mountain localities in the Vassfaret area (southern Norway). Norw. J. Zool., 22: 177-205.

Einsle, U. 1972. Die räumliche Verteilung einiger pelagisch lebender Crustaceen im Litoral des Mindelsees. Schr. Ver. Gesch. Bodensee Umgebg., 90: 259-269.

Einsle, U. 1975. Revision der Gattung Cyclops s.str., speziell der Abyssorum-Gruppe. Mem. Ist. ital. Idrobiol., 32: 57-219.

Einsle, U. 1989. The identification of copepodid instars of some calanoid and cyclopoid copepods of Lake Constance, Federal Republic of Germany. Crustaceana, 57: 79-87.

Elgmork, K. 1959. The seasonal occurrence of Cyclops strenuus strenuus. Folia Limnol. Scand., 11:1-196.

Elgmork, K. 1980. Evolutionary aspects of diapause in freshwater copepods. In: Kerfoot, W.C. (Ed.), Evolution and Ecology of Zooplankton communities. University Press of New England, Hanover, New Hampshire: 411-417.

Elgmork, K., J.P. Nilssen, T. Broch \& R. Øvrevik. 1978. Life cycle strategies in neighbouring populations of the copepod Cyclops scutifer Sars. Verh. int. Ver. Limnol., 20: 2518-2523.

Eriksson, M.O.G., L. Henrikson, B.-I. Nilssen, G. Nyman, H.G. Oscarson \& A.E. Stenson. 1980. Predator-prey relations important for the biotic changes in acidified lakes. Ambio, 9: 248-249.

Eriksson, F., E. Hörnström, P. Mossberg \& P. Nyberg. 1983. Ecological effects of lime treatments of acidified lakes and rivers in Sweden. Hydrobiologia, 101: 145-164.

Fryer, G. 1980. Acidity and species diversity in freshwater crustacean faunas. Freshwat. Biol., 10: 41-45.

Fryer, G. 1985. An ecological validation of a taxonomic distinction: the ecology of Acanthocyclops vernalis and $A$. robustus (Crustacea: Copepoda). Zool. J. Linn. Soc., 84: 165-180.

Fryer, G. 1998. The role of copepods in freshwater ecosystems. J. Mar. Syst., 15: 71-73.

Fryer, G. \& O. Forshaw. 1979. The freshwater Crustacea of Rhum (Inner Hebrides) - a faunistic and ecological survey. Biol. J. Linn. Soc., 11: 333-367.

Gliwicz, Z.M. 1967. Zooplankton and temperature-oxygen conditions of two alpine lakes of the Tatra Mountains. Pol. Arch. Hydrobiol., 14: 53-72.

Gliwicz, Z.M. \& M.G. Rowan. 1984. Survival of Cyclops abyssorum tatricus (Copepoda, Crustacea) in alpine lakes stocked with planktivorous fish. Limnol. Oceanogr., 29: 1290-1299.
Grossnickle, N.E. \& T.F. Næsje. 1993. Predation by the glacial relicts Mysis relicta and Heterocope appendiculata in Norwegian lakes. Verh. int. Ver. Limnol., 25: 470-473.

Gulati, R.D. 1984. The zooplankton and its grazing as measures of trophy in the Loosdrecht Lakes. Verh. int. Ver. Limnol., 22: 863-867.

Hairston, N.G. \& A.J. Bohonak. 1998. Copepod reproductive strategies: life history theory, phylogenetic pattern and invasion of inland waters. J. Mar. Syst., 15: 23-34.

Halvorsen, G. \& K. Elgmork. 1976. Vertical distribution and seasonal cycle of Cyclops scutifer Sars (Crustacea, Copepoda) in two oligotrophic lakes in southern Norway. Norw. J. Zool., 24: 143-160.

Hauge, H.V. 1942. Small lakes in Aust-Agder. Phytoplankton and some hydrographical factors. Skr. Vit. Akad. Oslo M.-N. K1.: 1-60.

Hebert, P.D.N. \& J.M. Loaring. 1980. Selective predation and the species composition of arctic ponds. Can. J. Zool., 58: 422-426.

Henriksen, A., A. Hindar, D. Hessen \& Ø. Kaste. 1977. Contribution of nitrogen to acidity in the Bjerkrheim River in southwestern Norway. Ambio, 26: 304-311.

Herbst, H.V. 1968. Die Copepoden des "Schwarzen Wassers" bei Wesel. Gewässer Abwässer, 46: 62-83.

Hessen, D.O. 1990. Niche overlap between herbivorous cladocerans: the role of food quality and habitat homogeneity. Hydrobiologia, 190: 61-78.

Hindar, A. \& J.P. Nilssen (Eds). 1984. Arsrapport Gjerstad 1982/84. Rep. Norw. Liming Project, 21-1984:1-153 (Mimeogr. in Norwegian).

Hindar, A., A. Henriksen, S. Sandøy \& A.J. Romundstad. 1998. Critical load concept to set restoration goals for liming acidificed Norwegian waters. Restaurat. Ecol., 6: 353-363.

Hobæk, A. \& G.G. Raddum. 1980. Zooplankton communities in acidified lakes in South Norway. SNSF-project, IR, 75/80: 1-132.

Hörnström, E., C. Ekström, E. Fröberg \& J. Ek. 1993. Plankton and chemical-physical development in six Swedish West Coast lakes under acidic and limed conditions. Can. J. Fish. aquat. Sci., 50: 688-702.

Hutchinson, G.E. 1957. A treatise of limnology. Volume I. Geography, physics, and chemistry. John Wiley Sons, NY.

Jackson, M.B., E.M. Vandermeer, N. Lester, J.A. Booth, L. Molot \& I.M. Gray. 1990. Effects of neutralisation and early reacidification on filamentous algae and macrophytes in Bowland lake. Can. J. Fish. aquat. Sci., 47: 432-439.

Jørgensen, I. 1972. Forandringer i strukturen til planktoniske og littorale Crustacea-samfunn under gjengroing av humusvann i området Nordmarka og Krokskogen ved Oslo, korrelert med hydrografiske data. Thesis, Univ. Oslo (Mimeogr. in Norwegian).

Kaste, Ø., P. Brettum, J. Håvardstun, E. Kleiven, F. Kroglund, E. Oug \& B. Walseng. 1999. Store Finnetjenn in Aust-Agder county. Chemical and biological development during 15 years of limning. NIVA-report, 4046-99: 1-74, (in Norwegian, summary in English).

Keller, W. \& N.D. Yan. 1998. Biological recovery from lake acidification: zooplankton communities as a model of patterns and processes. Rest. Ecol., 6: 364-375.

Keller, W., J.M. Gunn \& N.D. Yan. 1999. Acid rain - perspectives on lake recovery. J. Aquat. Eco. Stress Recovery, 6: 207-216.

Keller, W., N.D. Yan, T. Howell, L.A. Molot \& W.D. Taylor. 1992. Changes in zooplankton during the experimental neutralization and early reacidification of Bowland Lake near Sudbury, Ontario. Can. J. Fish. aquat. Sci., 49: 52-62.

Kiefer, F. 1976. Revision der robustus-vernalis-Gruppe der Gattung Acanthocyclops KIEFER (Crustacea, Copepoda)(Mit eingehenden Beurteilung des "Cyclops americanus Marsh, 1892"). Beitr. naturk. SW-Deutsch., 35: 95-110. 
Lacroix, G. \& F. Lecher-Moutoué. 1984. Diapause des Cyclopoides d'un écosystème lacustre peu profund (Lac de Créteil, France). Ann. Limnol., 20: 183-192.

Lair, N. \& M. Hilal. 1992. Acanthodiaptomus denticornis another omnivorous calanoid copepod. Description of its mouth appendages and feeding experiments on animal prey. Hydrobiologia, 248: 137-142.

Landry, M. R. 1978. Population dynamics and production of a planktonic marine copepod, Acartia clausii, in a small temperate lagoon on San Juan Island, Washington. Int. Revue ges. Hydrobiol., 63: 77-119.

Lampert, W. \& P. Muck. 1985. Multiple aspects of food limitation in zooplankton communities: the Daphnia Eudiaptomus example. Arch. Hydrobiol. Beih./Ergeb. Limnol., 21: 311-322.

Lowndes, A.G. 1952. Hydrogen ion concentration and the distribution of freshwater Entomostraca. Ann. Mag. Nat. Hist., 58(12): 58-64.

Luecke, C. \& W.J. O'Brien. 1983. The effect of Heterocope predation on zooplankton communities in arctic ponds. Limnol. Oceanogr., 28: 367-377.

Maier, G. 1990. Coexistence of the predatory cyclopoids Acanthocyclops robustus (Sars) and Mesocyclops leuckarti (Claus) in a small eutrophic lake. Hydrobiologia, 198: 185-203.

Maier, G. 1992. The reproductive cycle of Cyclops vicinus. J. Plankton Res., 14: 127-135.

Maier, G. 1994. Patterns of life history among cyclopoid copepods of central Europe. Freshwat. Biol., 31: 77-86.

Marmorek, D.R. \& J. Korman. 1993. The use of zooplankton in a biomonitoring program to detect lake acidification and recovery. Water Air Soil Pollut., 69: 223-241.

Monakov, A.V. 1972. Review of studies on feeding of aquatic invertebrates conducted at the Institute of Biology of inland waters, Academy of sciences, USSR. J. Fish. Res. Board Can., 29: 363-383.

Morling, G. \& B. Pejler. 1990. Acidification and zooplankton development in some West-Swedish lakes 1966-1983. Limnologica (Berlin), 20: 307-318.

Muck, P. \& W. Lampert. 1984. An experimental study on the importance of food conditions for the relative abundance of calanoid copepods and cladocerans. 1. Comparative feeding studies with Eudiaptomus gracilis and Daphnia longispina. Arch. Hydrobiol. Suppl., 66: 157-179.

Næss, T. \& J.P. Nilssen. 1991. Life cycle dynamics of a $C y$ clops strenuus (Crustacea, Copepoda) population with unusual diapause and reproductive characteristics. Arch. Hydrobiol., 122: 323-334.

Næss, T., J.P. Nilssen \& R. Demmo. 1993. Individual lake characteristics modify the life cycles and diapause habitat of two neighbouring populations of the cyclopoid copepod Thermocyclops oithonoides. Can. J. Zool., 71: 1663-1672.

Nassal, B., W. Burghard \& G. Maier. 1998. Predation by juvenile roach on the calanoid copepod Eudiaptomus gracilis and the cyclopoid copepod Cyclops vicinus: a laboratory investigation with mixed and single prey. Aquat. Ecol., 32: 335-340.

Niemi, G.J., P. Devore, N. Detenbeck, D. Taylor, A. Lima, J. Pastor, J.D. Yount \& R.J. Naiman. 1991. Overview of case studies on recovery of aquatic systems from disturbance. Environ. Manage., 14: 571-588.

Nilssen, J.P. 1978a. Selective vertebrate and invertebrate predation - some paleolimnological implications. Pol. Arch. Hydrobiol., 25: 307-320.

Nilssen, J.P. 1978b. On the evolution of life histories of limnetic cyclopoid copepods. Mem. Ist. ital. Idrobiol., 36: 193-214.

Nilssen, J.P. 1979. Problems of subspecies recognition in freshwater cyclopoid copepods. Z. zool. Syst. Evolut.forsch., 17: 285-295.
Nilssen, J.P. 1980. Acidification of a small watershed in southern Norway and some characteristics of acidic aquatic environments. Int. Revue ges. Hydrobiol., 65: 177-207.

Nilssen, J.P. 1982. Acidification in southern Norway: seasonal variation of aluminium in lake waters. Hydrobiologia, 94: 217-221.

Nilssen, J.P. \& K. Elgmork. 1977. Cyclops abyssorum - life cycle dynamics and habitat selection. Mem. Ist. ital. Idrobiol., 34: 197-238.

Nilssen, J.P. \& S. Sandøy. 1986. Acidification history and crustacean remains: some ecological obstacles. Hydrobiologia, 143: 349-354.

Nilssen, J.P. \& S.B. Wærvågen. 2000. Superficial ecosystem similarities vs. autecological stripping stripping: the "twin species" Mesocyclops leuckarti (Claus) and Thermocyclops oithonoides (Sars) - seasonal habitat utilisation and life history traits. J. Limnol., 59: 79-102.

Nilssen, J.P. \& S.B. Wærvågen. 2001. Kjemisk og biologisk "recovery" av forsurede innsjøer i Aust-Agder. Kakede vann og referansevann $i 1999$ og 2000. Fylkesmannen i Aust-Agder, Rapport nr. 2-2001: 1-80 (Mimeogr. in Norwegian). ISSN 0800-8523.

Nilssen, J.P. \& S.B. Wærvågen. 2002a. Intensive fish predation: an obstacle to recovery following liming of acid damaged lakes? J. Aq. Ecosyst. Stress Recov., 9: 73-84.

Nilssen, J.P. \& S.B. Wærvågen. 2002b. Recent re-establishment of the key species Daphnia longispina and cladoceran community changes following chemical recovery in a strongly acid-stressed region in southern Norway. Arch. Hydrobiol., 153: 557-580.

Nilssen, J.P., W.T.W. Potts \& T. Østdahl. 1984a. Fysiologi til zooplankton under forsurning og kalkning. Rep. Norw. Liming Project, 11-1984: 1-32 (Mimeogr. in Norwegian).

Nilssen, J.P., T. Østdahl \& W.T.W. Potts. 1984b. Species replacements in acidified lakes: physiology, predation and competition? Rep. Inst. Freshwat. Res. Drottningholm, 61: 148-153.

Nyberg, P. 1984. Impact of Chaoborus predation on planktonic crustacean communities in some acidified and limed forest lakes in Sweden. Rep. Inst. Freshwat. Res. Drottninholm, 61: 154-166.

Nyman, N.G. 1990. Some biological mechanisms reducing the availability of phosphorous in acid lakes. In: Manson, B.J. (Ed.), The surface water acidification programme, Univ. Press, Cambridge: 401-408.

Nyman, N.G., H.G. Oscarson \& J.A.E. Stenson. 1985. Impact of invertebrate predators on the zooplankton composition in acid forest lakes. Ecol. Bull. (Stockh.), 37: 239-243.

Oscarson, H.G. 1986. Studies on the ecology of water bugs (Corixidae) in changing environments. With spesial reference to the water boatman Glaenocorisa propinqua. Ph.D. Thesis, Univ. Gothenburg.

Raddum, G.G., J. Jastrey, B.O. Rosseland \& I. Sevalrud. 1979. Vannteger i Sør Norge og deres betydning som fiskeføde $i$ vann med ulik $p H$. SNSF-Project, IR, 50/79: 1-41 (Mimeogr. in Norwegian, summary in English).

Raddum, G.G., P. Brettum, D. Matzow, J.P. Nilssen, A. Skov, T. Sväelv \& R.F. Wright. 1986. Liming the acid Lake Hovvatn, Norway: A whole-ecosystem study. Water Air Soil Pollut., 31: 721-763.

Sandøy, S. \& J.P. Nilssen. 1987a. Life cycle dynamics and vertical distribution of Heterocope saliens (LILLJ.) in two anthropogenic acidic lakes in southern Norway. Arch. Hydrobiol., 110: 83-99.

Sandøy, S. \& J.P. Nilssen. 1987b. Cyclopoid copepods in marginal habitats: Abiotic control of population densities in anthropogenic acidic lakes. Arch. Hydrobiol. Suppl., 76: 236-255.

Santer, B. 1994. Influences of food type and concentration on the development of Eudiaptomus gracilis and implications 
for interactions between calanoid and cyclopoid copepods. Arch. Hydrobiol., 131: 141-159.

Santer, B. \& W. Lampert. 1995. Summer diapause in cyclopoid copepods: adaptive response to a food bottleneck? $J$. Anim. Ecol., 64: 600-613.

Santer, B., E. Blohm-Sievers, C.E. Cáceres \& N.G. Hairston jr. 2000. Life-history variation in the coexisting freshwater copepods Eudiaptomus gracilis and Eudiaptomus graciloides. Arch. Hydrobiol., 149: 441-458.

Skadovsky, S.N. 1926. Über die aktuelle Reaktion der Süsswasserbecken und ihre biologische Bedeutung. Verh. int. Ver. Limnol., 3: 109-144.

Skov, A. 1985. Livssyklus og tetthetsvariasjoner til zooplankton $i$ et skogstjern, Store Finnetjenn, Gjerstad, Aust-Agder 1980-1982. Thesis, Univ. Oslo: 131 pp. (Mimeogr. in Norwegian).

Snekvik, E. 1974a. Sure innsjöer og fiskebestand. Rapport nr. 2 Rogaland - Agder - Telemark. Direktoratet for vilt og ferskvannfiske, Ås-NLH (Mimeogr. in Norwegian).

Snekvik, E. 1974b. Om surt vann og ferskvannsfisk. Klipp fra fiskeriinnspektørens årsmeldinger i årene 1915 - 1961. Direktoratet for vilt og ferskvannfiske, Ås-NLH (Mimeogr. in Norwegian).

Snekvik, E. \& A. Sivertsen. 1975. Diagrammer for $p H$ of total hårdhet. Elveserie fra det sydligste Norge med referanseelver $i$ andre landsdeler, for perioden 1926 til og med 1974. Fiskeforskningen, Direktoratet for vilt og ferskvannsfisk, Ås-NLH (Mimeogr. in Norwegian).

Sprules, W.G. 1975a. Factors affecting the structure of limnetic crustacean zooplankton communities in central Ontario lakes. Verh. int. Ver. Limnol., 19: 635-643.

Sprules, W.G. 1975b. Midsummer crustacean zooplankton communities in acid-stressed lakes. J. Fish. Res. Bd Can., 32: 389-395.

Stenson, J.A.E., J.-E. Svensson \& G. Cronberg. 1993. Changes and interactions in the pelagic community in acidified lakes in Sweden. Ambio, 22: 277-282.

Stenson, J. \& J.-E. Svensson. 1994. Manipulations of planktivore fauna and development of crustacean zooplankton after restoration of the acidified Lake Gårdsjön. Arch. Hydrobiol., 131: 1-23.

Svensson J.-E. 1996. Predation on females and males of a freshwater copepod. Ph.D Thesis, Univ. Gothenburg.

Svensson, J.-E. 1997. Fish predation on Eudiaptomus gracilis in relation to clutch size, body size, and sex: a field experiment. Hydrobiologia, 344: 155-161.
Svensson, J.-E., L. Henrikson, S. Larsson \& A. Wilander. 1995. Liming strategies and effects: the Lake Gårdsjön case study. In: Henrikson, L. \& Y.V. Brodin (Eds), Liming of acidified surface waters. Springer Verlag, Berlin: 309325 .

Uye, S. 2000. Why does Calanus sinicus prosper in the shelf ecosystem of the Northwest Pacific Ocean? ICES J. Mar. Sci., 57: 1850-1855.

Wærvågen, S.B. 1985. En limnologisk studie av Gjerstadvann $i$ Aust-Agder, med spesiell vekt på zooplanktonsamfunnets livshistorier og populasjonsdynamikk. Thesis, Univ. Oslo: 177 pp. (Mimeogr. in Norwegian).

Wærvågen, S.W., N.A. Rukke \& D.O. Hessen. 2002. Calcium content of crustacean zooplankton and its potential role in species distribution. Freshwat. Biol. 47: 1866-1878.

Wærvågen, S.B. \& J.P. Nilssen. (2003). Major changes in pelagic rotifers during natural and forced recovery from acidification. Hydrobiologia: (in press).

Walseng, B. \& G. Halvorsen. 1993. Concervation status of watercources in Troms and Finmark, Northern Norway, with a focus on water chemistry and crustaceans. NINA Utredning, 54: 1-97 (in Norwegian, Abstact in English).

Walseng, B. \& H. Hansen. 1994. Crustaceans and bottomdwelling animal in acid waters in Østfold county. NINA Oppdragsmelding, 335: 1-29 (Mimeogr. in Norwegian, abstract in English).

Walseng, B. \& L.R. Karlsen. 1997. Recovery of acidification sensitive invertebrates in limed lakes in Østfold county. NINA Oppdragsmelding, 490: 1-32 (Mimeogr. in Norwegian, abstract in English).

Winfield, I.J. \& C.R. Townsend. 1983. The cost of copepod reproduction: increased susceptibility to fish predation. Oecologia (Berl.), 59: 406-411.

Yan, N.D. \& P.J. Dillon. 1984. Experimental neutralization of lakes near Sudbury, Ontario. In: Nriagu, J. (Ed.), Environmental impacts of smelters. John Wiley Sons, NY: 417-456.

Yan, N.D. \& C. Lafrance. 1984. Responses of acidic and neutralized lakes near Sudbury, Ontario, to nutrient enrichment. In: Nriagu, J. (Ed.), Environmental impacts of smelters. John Wiley Sons. NY: 457-521.

Yan, N.D. \& P.M. Welbourn. 1990. The impoverishment of aquatic communities by smelter activities near Sudbury, Canada. In: Woodwell, G.M. (Ed.), The earth in transition: Patterns and processes of biotic impoverishments. Cambridge Univ. Press. Cambridge: 477-494. 